\title{
Systematic Overview of Solid Particles and Their Host Responses
}

\author{
Fei Shu ${ }^{1,2}$ and Yan Shi ${ }^{1,3 *}$ \\ ${ }^{1}$ Department of Basic Medical Sciences, Institute for Immunology, Center for Life Sciences, Beijing Key Laboratory for \\ Immunological Research on Chronic Diseases, Tsinghua University, Beijing, China, ${ }^{2}$ Peking University-Tsinghua University- \\ National Institute of Biological Sciences Joint Graduate Program, School of Life Sciences, Peking University, Beijing, China, \\ ${ }^{3}$ Department of Microbiology, Immunology and Infectious Diseases, Snyder Institute, University of Calgary, Calgary, \\ $A B$, Canada
}

OPEN ACCESS

Edited by:

Hans-Joachim Anders, Ludwig-Maximilians-Universität München, Germany

Reviewed by:

Orestes Foresto-Neto, Universidade de São Paulo, Brazil Rahul D. Pawar The Scripps Research Institute, United States

Ramanjaneyulu Allam, Universität Bern, Switzerland

*Correspondence:

Yan Shi

yanshi@biomed.tsinghua.edu.cn

Specialty section:

This article was submitted

to Inflammation,

a section of the journal

Frontiers in Immunology

Received: 30 March 2018 Accepted: 08 May 2018

Published: 28 May 2018

Citation:

Shu F and Shi Y (2018) Systematic Overview of Solid Particles and Their Host Responses.

Front. Immunol. 9:1157. doi: 10.3389/fimmu.2018.01157
Crystalline/particulate substances trigger a plethora of signaling events in host cells. The most prominent consequence is the inflammatory reactions that underlie crystal arthropathies, such as gout and pseudogout. However, their impact on our health was underestimated. Recent work on the role of cholesterol crystal in the development of atherosclerosis and the harm of environmental particulates has set up new frontiers in our defense against their detrimental effects. On the other hand, in the last 100 years, crystalline/particulate substances have been used with increasing frequencies in our daily lives as a part of new industrial manufacturing and engineering. Importantly, they have become a tool in modern medicine, used as vaccine adjuvants and drug delivery vehicles. Their biological effects are also being dissected in great detail, particularly with regard to their inflammatory signaling pathways. Solid structure interaction with host cells is far from being uniform, with outcomes dependent on cell types and chemical/ physical properties of the particles involved. In this review, we offer a systematic and broad outlook of this landscape and a sage analysis of the complex nature of this topic.

Keywords: solid particle, host response, biological crystal, adjuvant, cell death

\section{INTRODUCTION}

Solid amorphous/crystalline/fibrous particles are common in our environment. Looking outward, all life forms are exposed to particles varying in size, chemistry, and the state of agglomeration in the surroundings. With the technological advancements, human populations are facing new variations related to the exposure to environmental and/or occupational pollutants/hazards/toxins. In recent times, nanotechnologies bring ultrafine particles into our lives (1). Therefore, we are in an everchanging world of particulate substances. Looking inward, several essential biological components are in delicate balance near the point of precipitation, including nucleic acid metabolites, lipids, and ions. Some forms of solidification, such as cholesterol crystal (CC) formation and calcification of joints, are a part of aging physiology. Other precipitations, such as monosodium urate (MSU) (2), can

\footnotetext{
Abbreviations: Alum, trivalent aluminum salts, including $\mathrm{ALOH}$ and $\mathrm{AlPO}_{4} ; \mathrm{BCP}$, basic calcium phosphate; CASR, calciumsensing receptor; CC, cholesterol crystal; CPPD, calcium pyrophosphate dihydrate; CVD, cardiovascular disease; DC, dendritic cell; LDH, layered double hydroxides; LDL, low density lipoprotein; HDL, high density lipoprotein; LLOMe, L-leucyl-L-leucine methyl ester; MLKL, mixed lineage kinase domain-like; MSU, monosodium uric acid crystal; NADPH, nicotinamide adenine dinucleotide phosphate oxidase; NET, neutrophil extracellular traps; NLRP3, NACHT, LRR, PYD domains-containing protein 3; RIPK1/RIPK3, receptor-interacting serine/threonine-protein kinase 1/3; ROS, reactive oxygen species; SERCA, sarcoplasmic/ER Ca ${ }^{2+}$-ATPase; TXNIP, thioredoxin-interacting protein; TLR, toll-like receptor; VLPs, virus-like particles.
} 
lead to acute inflammation and tissue damage. In addition, with advancements in modern medicine, pharma-biotech companies/ institutes introduce particles in formulation development for vaccination, drug delivery and cancer therapy. Compared with other areas of biomedical research, so far there has not been a discipline dedicated to studying how hosts respond to solid structures. As such, our understanding and theories are mostly fragmented, creating a hidden deficit in our effort to control and utilize this class of materials.

Host responses to solid/crystalline particles have been studied by scientists and clinicians for decades for health concerns. Historical lessons are vivid. One of the most memorable is the chrysotile and amphibole asbestos-induced respiratory deficiencies and mesothelioma $(3,4)$. The impact was that guidelines were imposed by regulatory bodies to strictly ban its consumer use and minimize it human exposure of occupational operators (https:// www.epa.gov/asbestos). In recent years, cellular signaling events associated with crystal-triggered inflammation have become an intensely investigated topic (5). Some areas are covered with extreme depths, including inflammasome activation (6), cell death (7-9), reactive oxygen species (ROS) production $(10,11)$, and adjuvanticity $(12,13)$. However, crystals vary greatly in their geometry and chemistry. Host cells with whom they interact are also diverse. Therefore, the speedy accumulation of newly gained knowledge has not led to a sufficient number of consensuses. In addition, a solid structure/host cell response cannot be comprehended at any given cross section. It is a chain of events from crystal formation/entry, cell membrane binding, intracellular signaling cascades, cytokine release, cell death, secondary host responses, etc. In this review, we aim to integrate several less illuminated areas of cell responses to solid particles, including physiochemical properties, nanoparticles, particulate adjuvants, and ongoing debates regarding their activation mechanisms. In other words, we offer a panoramic view of this interesting topic.

\section{PHYSICAL AND CHEMICAL PROPERTIES}

While research on signaling events in host response to solid particles is currently very active, the study of their chemical and physical properties remains a widely pursued subject. As particles under analysis and experimental readouts vary, it is hard to draw a set of conclusions with any precision. The overarching observations are: (1) Size of any given solid structure has a great impact on its biological effects. (2) A given volume of a particulate substance can have different effects depending on their geometric parameters. (3) Surface chemistry, including coating, can change outcomes. (4) Different host cell types can manifest different host responses. However, if the nature and types of experimental outcomes can hypothetically be set aside, and only activation intensity (i.e., cytokine production, adjuvanticity, and cellular morphology changes) is used as the readout, some internal consistencies can be extracted from the existing literature.

\section{Size}

Generally, solid structures of size $1-100 \mathrm{~nm}$ are considered as nanoparticles. For these particles, the general entry into the cells is mediated by endocytosis or simple diffusion without any defined receptors. Sizes beyond $100 \mathrm{~nm}$ and up to $10 \mu \mathrm{m}$ are regarded as microcrystals. Within the latter, for particles with a diameter larger than $0.5 \mu \mathrm{m}$, phagocytosis is the dominant form of entry (14). There have been some isolated studies (15-17) whereby the size of polylactide-co-glycolide (110 vs $800-900 \mathrm{~nm}$ ) did not show any significant changes in the ability to induce antibody responses to protein antigens from Neisseria meningitidis and HIV in mice (18). However, most papers appear to offer different results (1). Early work using simple stimulation and cell proliferation index measurement suggested that larger surface area (smaller diameter) of polystyrene and $\mathrm{TiO}_{2}$ particles seemed to block macrophage cell line proliferation in vitro (taken as an indicator of cell loss) (19). This finding was confirmed by another group where carbon black as well as $\mathrm{TiO}_{2}$ particles were used in vivo. In that study, both particles of $250 \mathrm{~nm}$ in diameter and those roughly one log smaller were instilled intratracheally. In rats, the smaller ultrafine particles induced drastically higher neutrophil infiltration in the lung and greater epithelial damage (20). Using epithelial cells as an example, amounts (total volume) required for small (below $20 \mathrm{~nm}$ ) vs large (above $100 \mathrm{~nm}$ ) silica crystals tended to create a log difference in the efficiency of inducing cell death. In addition, smaller particles achieved the same effect much faster than the larger ones in human endothelial cells in vitro (21). Similar observations were made by other groups studying human endothelial cells and macrophage in vitro (22). One reason for this difference is that small particles enter cells more readily. Using silver nanoparticles (SNP) SNP-5, SNP-20, and SNP-50 (numbers indicate diameter in nanometer) as an example, in vitro cellular toxicity of smaller particles was correlated with their rapid presence inside the human epithelial cells (23). In one report that compared nano vs micro silica particles, smaller (30-1000 nm) crystals entered mouse BMDM easily and caused significant lysosomal marker loss, indicating lysosome destabilization, in comparison with the larger ones $(1,000-10,000 \mathrm{~nm})(24)$. An interesting contrast was another paper suggesting that silica particles $1,000 \mathrm{~nm}$ across were more toxic than small ( $30 \mathrm{~nm})$ to THP-1 cells (25), a phenomenon associated with the efficient uptake of the larger particles. This study, as well as several others, suggested that phagocytes, such as J774.2 and RAW264.7 cells, were more prone to particle-induced cell damage than nonphagocytic cells (L929) (26). These results imply that efficient entry may ultimately explain the ability to trigger cellular responses. Whether additional signaling mechanisms related to particle size also account for the stimulation intensity have not been independently investigated.

\section{Morphology and Geometry}

Shape of solid structures has been implicated in some studies to be a critical factor in triggering host cell responses. The differences in crystalline symmetry, i.e., anatase vs rutile $\mathrm{TiO}_{2}$, could result in significantly different outcomes in mouse keratinocytes in vitro (27). The sharp and pointy edges of many crystals, i.e., asbestos and MSU, are believed to at least partially contribute to their pathology via direct injury to mouse mesothelial cell membrane in vitro and in vivo $(28,29)$. Using non-opsonized hydroxyapatite (HA) as an example, a study was conducted to compare four types of geometries: needle, plate, sphere, and rod 
and tested their ability to induce TNF $\alpha /$ IL- 6 and ROS production as well as cytotoxicity. It was found that needle and plate shapes induced the highest rate of cell death in human bronchial epithelial cells accompanied by high IL- 6 production. Interestingly, rod-shaped HA induced more ROS production. RAW264.7 cells, on the other hand, showed much less selectivity to the shape in all the parameters measured (30). A study on carbon nanotubes (CNTs) also suggested that long and needle-shaped CNTs and asbestos triggered human macrophage IL-1 $\beta$ secretion in vitro while only the former triggered IL- $1 \alpha$ production. Carbon black and short CNTs failed to induce either (31). Interestingly, in this report, it was found that long CNTs induced a typical NACHT, LRR, PYD domains-containing protein 3 (NLRP3) inflammasome activation event that relied on ROS production, P2X7 receptor, and lysosomal destabilization. Long silver nanowires were also more inflammatory toward human epithelial and liver cells in vitro than the short ones (23), and spherical $\mathrm{TiO}_{2}$ was less stimulatory than the same material in the shape of nano belts in vivo (32). The observations may be associated with higher area/ volume ratio, although a systematic analysis is not yet available. In a study comparing crystalline nanocellulose with fibrillary cellulose, it was found in A549 cells fibrillary cellulose was more toxic than the crystalline counterpart. This was mainly due to the former's strong ability to induce oxidative stress. On the other hand, crystalline cellulose was able to induce a broad range of cytokine production including IL-6, IL-8, MCP-1, IL-12p70, and G-CSF (33). Therefore, distinct shapes with similar chemistry can lead to different profiles of cellular responses. Many crystalline structures may also exist in an amorphous state by contrast to the better known larger crystals. In a pulmonary inflammation mouse model, amorphous/colloidal silica induced only transient inflammation while the response triggered by crystals was more persistent (34). Indeed, for non-crystalline structures such as $\mathrm{SiO}_{2}$ from nano to micro $\mu \mathrm{m}$ sizes (mono-disperse and poly-disperse), the stimulation for NLRP3 inflammasome activation in mouse macrophages was lower than the crystalline. On the other hand, the comparison between amorphous and colloidal forms did not reveal any difference in stimulation capacity (35).

\section{Chemical Composition}

Chemical properties of solid structures have been directly linked to their stimulatory ability. Under this umbrella, one consideration is the degree of solubility. It is generally considered that solubility is proportionally related to cytotoxicity (36). In several reports, slightly soluble zinc and iron oxides were more potent in inducing target cell DNA release than almost insoluble $\mathrm{CeO}_{2}, \mathrm{ZrO}_{2}, \mathrm{TiO}_{2}$, and $\mathrm{Ca}_{3}\left(\mathrm{PO}_{4}\right)_{2}$. In one study, ionic metal was critical to IL-6 and IL-8 production by human airway epithelial cells which were blocked by metal chelation (37). However, mechanistic insights of the observations of this nature are not available $(38,39)$. In the absence of detectable solubility, chemical composition can also make a difference in cellular responses. By comparing various metal oxides, copper oxide had the highest toxicity toward airway epithelial cells (40). In that study, several metal oxides were equally potent to induce ROS in the treated cells, however, $\mathrm{CuO}$ had the ability to suppress the cellular antixidation effects, i.e., the activities of catalase and glutathione reductase. It should be noted that depending on cell types studied and experimental settings, results have not been consistent regarding chemical compositions of particles. In some studies, $\mathrm{Y}_{2} \mathrm{O}_{3}$ (yttrium oxide) and $\mathrm{ZnO}$ were found to trigger inflammatory responses (ICAM-1, MCP-1, and IL- 8 expression) better than $\mathrm{Fe}_{2} \mathrm{O}_{3}$ in endothelial cells (41), by contrast with the report by Brunner et al. where iron oxides were more stimulatory in human mesothelioma and rodent fibroblast (36). Surface charge and hydrophobicity may also affect cellular responses in vivo (42-44). This notion was echoed by a study where unmodified silica crystals induced strong IL-1 $\beta$, ROS, and NLRP3 inflammasome activation in THP-1 cells. However, surface functionalization with $-\mathrm{COOH},-\mathrm{NH}_{2},-\mathrm{SO}_{3} \mathrm{H}$, and - $\mathrm{CHO}$ groups significantly reduced all aspects of inflammatory responses (45). In fact, the simple presence of cell culture serum can result in significant reduction of toxicity toward fibroblast, which presumably was driven by the alteration of particle surface chemistry (46). Interestingly, the different surface chemistry can also alter their anatomic distributions. For instance, i.p. injected polymethyl methacrylate beads tended to deposit in the spleen resulting in its enlargement. Polystyrene beads of similar sizes, on the other hand, were accumulated in adipose tissues (47). Likely the different surface chemistries triggered different migration patterns in the phagocytosing macrophages.

It should be noted that the forth mentioned experimental results are small samples of the vast literature on chemical/ geometric properties of host-interacting particles. Depending on cell types, readouts, and experimental settings, different and even contradictory reports are common. Ideally, the desired approach is to isolate one particular variable for extensive analysis while other parameters are meticulously controlled. Thus far, the boldest attempt to extract a set of principles underneath the surface chemistry and immune recognition was made by Williams et al. (48). In that study, they used "layered double hydroxides" (LDH) for analysis, prompted by the effect of alum in immune stimulation. The exact chemical compositions are technically challenging to understand. We can picture their setup as follows. A sheet of metal $\left(\mathrm{M}^{+} \mathrm{M}^{2+}\right.$ and $\left.\mathrm{M}^{3+}\right)$ hydroxides is laid against pairing anions to form a stack. Each stack is laid on top of another for a multilayered structure. Because the metal ions can be chosen, $\mathrm{M}^{+} \mathrm{M}^{2+}$ vs $\mathrm{M}^{3+}$ ratios and anion species can be selected, the resulting structures can be tested for their immune regulation solely as a function of various ions used in the experiment. Dendritic cell (DC) activation was measured by a set of cytokine production. $\mathrm{LiAl}_{2}-\mathrm{CO}_{3}, \mathrm{Mg}_{2} \mathrm{Al}-\mathrm{NO}_{3}, \mathrm{Mg}_{2} \mathrm{Fe}-\mathrm{Cl}$, Imject alum, and alhydrogel were compared. Surprisingly, this study revealed that all in vitro human DC responses were highly correlated with a linear combination of three $\mathrm{LDH}$ properties: the radius of the spherical $\mathrm{M}^{+}$or $\mathrm{M}^{2+}$ metal cations; the distance between the $\mathrm{LDH}$ layers (interlayer spacing); and zeta potential that defines the magnitude of the electrical charge at the interfacial double layer around the LDH particle. Newly synthesized LDHs were highly predictable by these variables in their DC stimulatory capacity. These properties were directly verified in in vivo mouse antibody production. These efforts were aimed to produce a set of "chemical-immunology rules". Clearly, to understand the complex nature of host responses to solid structures, undertakings like this point to a possible angle to tackle the vast unknowns of 
physics and chemistry of particulate substances involved in host cell activation.

\section{BIOLOGICAL CRYSTALS}

Unlike particles that come with modern manufacturing/processing or exist in our environment, crystalline deposition has long been a part of human biology/pathology. Best known among them are uric acid, cholesterol, heme, and a list of calcium-containing crystals [calcium pyrophosphate dihydrate (CPPD), HA, calcium oxalate, and calcium phosphate family in general]. Slightly less prevalent diseases can be caused by additional crystals, such as xanthine leading to xanthinuria and arthropathy (49) and cystine (oxidized cysteine dimer) in kidney stones (50). A rare genetic disease, adenine phosphoribosyltransferase deficiency, results in the inability to produce adenosine monophosphate from adenine, 2,8-dihydroxyadenine crystal formation, and kidney failure in human and mice (51-54). In this section, we aim to illustrate the most common types and their related pathologies.

\section{Monosodium Urate Crystals}

Gout, the deposition of MSU crystals, has been recognized for over 4,000 years and extensively described in the ancient literature (55). Historically, its occurrence has been associated with excessive dietary and alcohol consumption (56). In the $18^{\text {th }}$ century, crystals from a tophaceous joint were isolated and their chemical nature was reported (55). It is generally believed that high purine metabolism leads to hyperuricemia $(>6.8 \mathrm{mg} / \mathrm{dl})$, a precondition for gout and tophus. Gout is often induced by metabolic and environmental factors, such as increased $\mathrm{Ca}^{2+}$, low $\mathrm{pH}$, and cold weather, and occurs only in the distal extremities, never near the core of body where the temperature is more consistent (57). Interestingly, till date, we still cannot duplicate the in vivo crystal formation event in the lab, as at this concentration uric acid does not precipitate in standard buffers (58). Additional factors, for instance natural MSU antibodies, may be critical for this process $(58,59)$. Mechanistically, in vivo the initial nucleation of uric acid crystals is reversed due to rapid dissolution. The antibodies (IgG in human gout patients and IgM in mouse) help stabilize the nucleation core whereby the crystal growth is permitted. This notion is supported by clinical observations that MSU crystals isolated from patients are often coated with a layer of antibodies (60), with Fab pointing to the crystalline surface (61). Regarding the signaling events leading to the painful inflammatory episode of gouty arthritis, many models have been proposed. MSU typically activates NLRP3 inflammasome and IL- $1 \beta$ production, and the proposed signaling events pertinent to NLRP3 regulation, such as ROS, $\mathrm{K}^{+}$efflux, and lysosomal rupture, are all implicated in its inflammatory properties (discussion later). Specific to MSU, it has been suggested that CD11b and CD16 may directly recognize MSU crystals because antibodies for these two surface molecules reduced MSU-mediated neutrophil activation $(62,63)$. Interestingly, the antibody blockage also reduced neutrophil responses to CPPD, a chemically distinct structure, suggesting that these surface molecules may merely participate in the signaling rather than the specificity determinant for these crystalline surfaces. Liu-Bryan and Terkeltaub's group reported that toll-like receptor (TLR)2/TLR4 and CD14 were the functional receptors of MSU (64-66). The conclusion was mostly drawn from the reduced inflammatory responses in mice deficient in these genes. Using similar TLR-deficient mouse models as well as in vitro cell transfection, Chen et al. failed to see any involvement of TLR2 or TLR4 (67). While the suggestion of protein-based positive signaling receptor for MSU has not been further investigated, one paper suggested that Clec12a is an inhibitory receptor for this crystal. Binding analysis showed that Clec12a had specific affinity for MSU and mice deficient in this gene mounted increased inflammatory responses against MSU challenge (68). Our lab's results have suggested another model. The surface of MSU crystal showed substantial binding to cholesterol, a component of lipid rafts. The binding event caused the plasma membrane lipid sorting and an accumulation of ITAM-containing membrane proteins. This accumulation, in turn, recruited Syk to the inner leaflet and induced a chain reaction similar to Syk/PI3K-dependent phagocytic activation (69). This model describes a lipid-based signaling event independent of protein receptors. Whether this signaling modality is central to the general sensing of solid structures and is being actively investigated.

\section{Calcium Crystals}

While calcium salt crystals mediate inflammatory responses similar to MSU (70), the prerequisites for their formation are different. First, calcium-containing crystal generation does not require elevated levels of $\mathrm{Ca}^{2+}$. Second, these crystals almost always develop on matrix surfaces, mostly cartilages (71). Inorganic pyrophosphate, produced via ATP metabolism, is found to induce CPPD formation. On cartilages, inorganic pyrophosphate level is regulated by several enzymatic activities including ectonucleotide pyrophosphatase $(72,73)$. Unlike MSU, calcium crystal deposition in joints is common and remains asymptomatic in most adults, and it is, therefore, difficult to directly link CPPD formation to the symptoms of pseudogout (74). In model systems with synthetic crystals, CPPD does stimulate strong inflammatory activation. Therefore, the prevailing proposal is that CPPD formation is an essential first step for the eventual development of the acute "gout" like symptoms (75). Signaling-wise, CPPD and basic calcium phosphate can stimulate nitric oxide and collagenase production in chondrocytes in vitro $(76,77)$. Martinon et al. found that CPPD is a strong inducer of NLRP3 inflammasome activation in vitro (6). In addition, CPPD crystals can inhibit neutrophil apoptosis via Bcl-2 (78). It is very likely that all these factors work in sync to generate the inflammatory responses to calcium salt crystals.

\section{Cholesterol Crystals}

Cholesterol clustering in vivo is primarily in two forms. Gallstones (cholelithiasis) are large solid structures mostly made of cholesterol in biliary duct and gallbladder. They are results of liver cholesterol accumulation, often with a genetic disposition (79). The presence of CC in atherosclerotic lesions reflects the imbalance of cholesterol homeostasis and has by far the highest impact in human health, being one of the root causes of cardiovascular disease (CVD, a third of mortality in the developed countries). $\mathrm{Via}$ the mevalonate pathway, all mammalian cells are capable of 
cholesterol synthesis (80). Its metabolism is mainly in the liver in the form of biliary secretion of surplus cholesterol and bile acid. Therefore, the cholesterol transport becomes the critical regulation of its level. For the cardiovascular system, low density lipoprotein via its receptor transports esterified cholesterol to artery walls while high density lipoprotein mediates the reverse transport back to the liver (81). In the periphery, deposited esterified cholesterol can be converted by ester hydrolases into free cholesterol, leading to CC formation (82). In advanced CVD, accumulated $\mathrm{CC}$ in the plaques expand in volume and cause the rupture of the fibrous cap, leading to acute thrombosis, embolism, and clinical CVD symptoms $(83,84)$. More in depth analyses indicate that CC may be the culprit of the initial atherosclerotic change at the very beginning. It was found by some that cholesterol-lowering treatment was only beneficial when used early in mouse life (85). Because of their small sizes, optical imaging in tissues has not been easy. The limitation is being gradually overcome with new preparation protocols $(86,87)$ and imaging tools such as Raman scattering microscopy (88). A recent paper reported that endothelial cells produce CC rather quickly under cholesterol overload. The crystal deposition under endothelial cells was found as early as 1 week after feeding $L d l r^{-1-}$ mice with high fat diet (89). Those improved detections strongly suggest their involvement in much of the initial atherosclerotic development. Local accumulation of CC has been recognized as an inflammatory event (90). CC can activate the complement system in vitro $(91,92)$ as well as IL- $1 \alpha$ production in vivo and in vitro $(93,94)$. The central interest is undoubtedly focused on the involvement of NLRP3 inflammasome. Some reports suggested that NLRP3 inflammasome and its components were essential for the plaque formation $(86,95)$ while others failed to make this observation $(93,96)$.

\section{Hemozoin}

Malaria is a major cause of mortality in developing countries. In its life cycle, Plasmodium invades red blood cells and uses hemoglobin as its energy source. The product of this digestion, heme, forms hemozoin crystals (97). While Plasmodium itself can directly modulate endothelial permeability and cause circulation blockage $(98,99)$, hemozoin is a major activator of innate immunity (100), both leading to various degrees of mouse hepatocyte dysfunction in vivo (101). The surface of hemozoin crystals has been found to be highly active in mediating oxidative responses (102). Another property of hemozoin is its extensive phagocytosis by phagocytes in the circulation and in vital organs (liver, brain, etc.), particularly after RBC rupture (103). This phagocytic event is believed to be immune regulatory and the intensity of phagocytosis is an indicator of the disease severity (104). Macrophages and monocytes stimulated with hemozoin produce large amounts of cytokines in vitro, including $\mathrm{TNF} \alpha$, MIP1 $\alpha$, and $\beta$ (105), chemotactic factors (106), ROS and nitric oxide $(100,107)$. A large panel of signaling molecules, including ERK1/2, JAK2/STAT-1, NFkb, and Syk kinases were all reportedly involved (108). The exact recognition mechanism is not clear, although in one report TLR9 was involved (109). This finding is controversial as others have suggested the contamination of Plasmodium DNA in the isolated hemozoin (110-112). By contrast, the activation mediated by NLRP3 is well characterized and has been supported by multiple research groups. Shio et al. found that hemozoin-induced NLRP3 inflammation and IL-1 $\beta$ production were downstream of Syk kinase. Importantly, deficiencies in NLRP3 components protected the host from one strain of malaria, Plasmodium chabaudi adami (113). Another paper around the same time suggested that hemozoin mediated inflammatory responses in vitro and in vivo, particularly NLRP3 activation, was via induction of uric acid release (110).

\section{PARTICULATE ADJUVANTS}

Adjuvants are used to increase host responses to otherwise low immunogenic antigens. They can be roughly divided into delivery tools and immune potentiators $(12,114)$. Serving both purposes, particulate adjuvants are a subcategory of immune enhancers and are the first preparation used in human vaccine. Glenny's work has been sufficiently discussed in vaccine reviews (115). However, one particular point worth noting is that while the early workers Glenny and Maschmann et al. used alum in various chemical composition to precipitate and stabilize diphtheria toxin, they did not recognize the immune stimulatory effects of this crystalline structure (116-118). In the last two decades, our understanding of particulate adjuvants has seen some dramatic revisions.

Alum usually refers to trivalent inorganic aluminum salts, including $\mathrm{Al}(\mathrm{OH})_{3}$ and $\mathrm{AlPO}_{4}(119,120)$. For decades, it was thought that alum served as an in vivo depot for the associated antigens, prolonging antigen availability. This notion was proven incorrect by several experiments (121-123). In 2004, it was reported that injection of alum resulted in the accumulation of IL-4-producing monocytic Gr1 ${ }^{+}$cells in the spleen (124). Till date, it is still not clear how this population mediates immune response, although it is involved in TH1/TH2 bias (125). In 2008, Eisenbarth et al. reported a deficiency in multiple antibody subtype production in response to alum in $\mathrm{NLRP}^{-/-}$mice (126) suggesting that alum's immunogenicity may be related to its ability to activate NLRP3 inflammasome. A follow-up paper using similar mouse models by Tschopp's group, however, reported a reduction in IgE production only (127). In other reports, including from our own group, NLRP3/Caspase-1 axis was not found to be essential for alum-mediated antibody production (128-130). Later on, two groups reported that DNA release triggered by local alum injection might be responsible for its adjuvanticity $(131,132)$. Ishii's group further suggested that in the process, alum triggered activation of TBK1/IRF3, leading to IgE isotype switching (132). Whether this signaling event requires STING, a sensor for intracellular DNA is still a topic of discussion (131). In addition, a recent paper suggested that commercially available DNase may have proteolytic activities, which at least partially explained the reduced adjuvanticity following DNA removal in alum-treated mice (133). Therefore, the role of DNA release in alum's adjuvant effect still requires more carefully controlled analyses. Our group proposed an alternative mechanism. Using atomic force microscopy, we found that alum crystals bound to DC plasma membrane lipids and triggered an abortive phagocytic response. DCs thus activated showed enhanced binding to $\mathrm{CD}^{+}$T cells via ICAM-1 and LFA-1 (128), leading to better T cell priming by DCs. 
The notion that uric acid being a particulate immune adjuvant was not derived from its ability to trigger gouty inflammation. It was found that dead cells had strong adjuvant effect when delivered with protein antigens; the active fraction was molecularly identified by chromatography and mass spec analysis (134). It was found that soluble uric acid did not have any adjuvant effect, yet it turned stimulatory upon crystallization. It has been difficult to visualize MSU deposition in vivo following immunization because the microcrystals were not compatible with imaging preparation protocols. Although the ability of uric acid to serve as an adjuvant is confirmed (135) in recent years, MSU has been gradually recognized as a "cryptic" adjuvant, in that many immune responses appear to require background uric acid. We have reported that MSU crystallization requires endogenous antibodies that stabilized the initial crystal formation. In the absence of antibody as in the $\mathrm{IgH}$ mice, uric acid did not serve as an endogenous adjuvant (58). Several reports have found that removal of uric acid in vivo significantly reduced airway inflammation (136) and immune responses to antigens released from dead cells $(2,137)$. In addition, other groups have found that uric acid may be the conduit for the immune stimulatory effect of hemozoin and alum adjuvant $(110,138)$.

Virus-like particles (VLPs) are a relatively new technology and originated from the vaccine preparation with killed pathogens. They are assembled viral proteins with a resulting morphology similar to original viruses. These particles are highly stimulatory in comparison with their soluble proteins and at the same time free from the safety concerns associated with attenuated virions. With recombinant technologies, bacterial, viral, mammalian, and other expression systems have been used to successfully produce VLPs. Although VLPs can be considered adjuvants in comparison with free proteins, their efficacy can be further enhanced by other adjuvants (139). The mechanistic basis for the enhanced immunity is a concept termed geometric pathogen-associated structural pattern (140). In general, all VLPs form unique repetitive surface structures $(140,141)$. As these patterns bare the signature of invading pathogens, they are potent in activating antigen presenting cells and mediate efficient migration of these cells to draining lymph nodes. They are also able to bind to naturally existing antibodies and fix complement (142), further enhancing their immune stimulation.

Nanoparticle adjuvants were a product of time that started two decades ago. The term defines the size but posits no limitation on its chemical/structural details. One of the most frequently tested is polylactic-co-glycolic acid and polylactic acid, for their biodegradability and easy incorporation of antigens and drugs (143). They are known to induce antibody titers similar to those adjuvanted regimens. Other popular selections are liposome and micelle-based preparations. Overall, nanoparticles can easily enter solid tumors (144). This is likely the result of extensive pathways used for the uptake of these particles, including pinocytosis, and clathrin and caveolin-dependent endocytosis (145). These particles have been used as an efficient tool for delivery mainly due to their protection $(146)$ and controlled release $(147,148)$ of associated antigens. Similar to other particulate antigens, nanoparticles can trigger cross-presentation and $\mathrm{CD}^{+} \mathrm{T}$ cell responses (149), a feature sought in viral vaccine and tumor immune therapy.

\section{SOLID PARTICLE-INDUCED HOST CELL RESPONSES}

\section{Inflammasome}

Solid/amorphous/crystalline/fibrous structure-mediated cellular responses are a major part of inflammasome research, particularly signaling associated with NLRP3 inflammasome. In 2006, Tschopp's group reported that MSU and CPPD-induced IL-1 $\beta$ production was dependent on NLRP3 inflammasome components, NLRP3, ASC, and caspase-1 (6). This landmark experiment started the intense pursuit of inflammatory mechanisms associated with solid particles. Subsequently, a series of papers described the requirement for NLRP3 in IL-1 $\beta$ production in response to silica, asbestos, and metal oxides. With limited exceptions, it is reasonable to assume that the bulk of inflammation associated with solid structures is dependent on NLRP3 inflammasome. However, the molecular events that lead to NLRP3 activation are still being debated. Several intermediate conduits have been proposed including ROS production, lysosome rupture, $\mathrm{K}^{+}$ efflux, and $\mathrm{Ca}^{2+}$ influx $(150,151)$.

\section{Reactive Oxygen Species}

In the process of ATP production in mitochondria, oxygen is ideally reduced to water. However, when this process is not complete, $\mathrm{O}_{2}^{-}$escaped from this pathway becomes the source of a series of oxidizing chemicals, including hydrogen peroxide and hydroxyl radicals (152), collectively termed as ROS. These products become a part of cellular signaling network-redox biology. ROS signaling is also essential for both innate and adaptive immunity $(153,154)$. The excess of this production leads to oxidative stress, which is at the core of cellular aging and degenerative diseases such as sclerosis and neoplasm. ROS production can be readily induced by solid structures of various sizes and shapes, and to some extent of distinct chemical compositions. Many nanoparticles, copper, iron, cerium, zinc, nickel, titanium, aluminum oxides, gold, silver (155), silica (156), MSU (157), asbestos (158), and alum were found to induce ROS. ROS blockade with ROS scavenger or inhibition of nicotinamide adenine dinucleotide phosphate oxidase (NADPH) oxidase suppressed NLRP3 activation induced by MSU, asbestos (159), silica (158), and hemozoin (160). In the process, the conduit was proposed to be thioredoxin-interacting protein (TXNIP). TXNIP dissociates from thioredoxin in a ROS-sensitive manner and then binds to NLRP3 leading to its activation (157) (Figure 1). This proposal has not been completely satisfactory. First, a lot of stimuli induce ROS production but NLRP3 activation is not common to all of them, i.e., cytochrome P-450 oxidase uncoupling, xanthine oxidase activation, mitochondrial respiration, and various peroxisome oxidase activations (161). Inflammasome activation was not increased but suppressed in enhanced production of ROS in superoxide dismutase-1-deficient macrophages (162) while NADPH oxidase deficiency boosted the activation (163). Second, the source of ROS responsible for NLRP3 inflammasome activation remains unclear. The inhibition of mitochondrial complex I and II did not reduce asbestos-induced NLRP3 activation in vitro (159), arguing against mitochondria as the origin of ROS. 


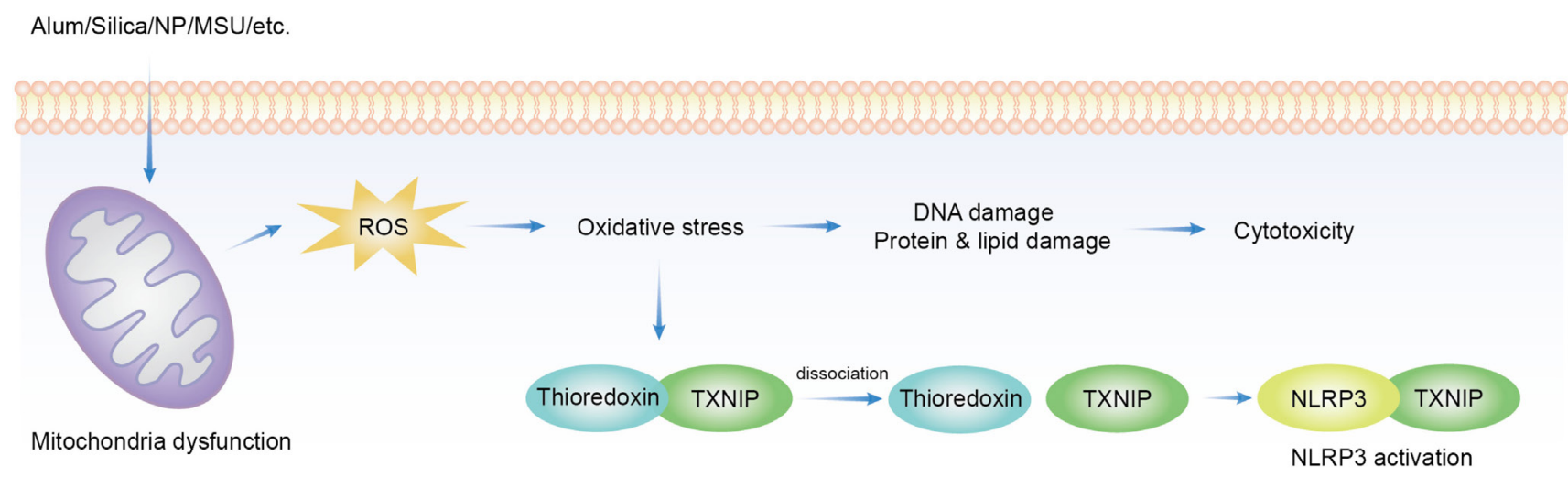

FIGURE 1 | Overview of reactive oxygen species (ROS) implicated in solid particle-induced cell death and NACHT, LRR, PYD domains-containing protein 3 (NLRP3) inflammasome activation. Solid particle treatment causes mitochondrial stress and ROS production. The oxidative stress mediates the damage of DNA, proteins, and lipids, which may be an important cause of cytotoxicity. ROS production also induces NLRP3 inflammasome activation by dissociating thioredoxin-interacting protein (TXNIP) from thioredoxin then allows its binding to NLRP3, which leads to NLRP3 activation.

\section{Lysosomal Rupture}

Another leading proposal for crystal-mediated NLRP3 inflammasome activation is via lysosome rupture. In this model, phagocytosis of solid particles triggers lysosome destabilization and release of cathepsin B, which activates NLRP3. Lysosome rupture blockage and cathepsin B inhibitor reduced NLRP3 activation in mouse macrophages in vitro induced by alum (164) and silica (165). Artificial induction of lysosome rupture with L-leucylL-leucine methyl ester (LLOMe) also led to NLRP3 activation that was blocked by cathepsin B inhibitor (166). However, this notion is controversial. In some reports, cathepsin B deficiency failed to reduce IL-1 $\beta$ production in vitro stimulated by MSU and silica $(151,167)$ or hemozoin $(160)$. A possible explanation for this contradiction is the off-target effect of cathepsin B inhibitor as it was found to block NLRP1b inflammasome (168). Another explanation is that multiple cathepsins are involved in NLRP3 activation as the cathepsin family is highly conserved and cathepsin B inhibitor, Ca074Me, was found active toward other members (169). Furthermore, the authors found that not only NLRP3 activation but also particle-induced cell death was dependent on multiple redundant cathepsins $(169,170)$.

\section{$\mathrm{K}^{+}$Efflux}

In recent years, the role of $\mathrm{K}^{+}$efflux in NLRP3 activation has become the center of attention. High extracellular $\mathrm{K}^{+}$was reported to inhibit almost all known NLRP3 agonists in vitro, including hemozoin (160), silica and asbestos (159), MSU, Nigericin, and ATP (171), and bacterial pore-forming toxin, alum, CPPD, and LLOMe (151). Glyburide, a $\mathrm{K}^{+}$channel blocker, also inhibited NLRP3 inflammasome in vitro (172), which appears to confirm the role of $\mathrm{K}^{+}$efflux. The intracellular sensor for the reduced $\mathrm{K}^{+}$and how it is linked to NLRP3 activation are not clear. The idea of $\mathrm{K}^{+}$efflux as the upstream signal of NLRP3 came from the understanding that extracellular $\mathrm{K}^{+}$blocks intracellular $\mathrm{K}^{+}$ outward motion during a typical cycle of eukaryotic membrane depolarization/repolarization (171) and assumed that particulate substances triggered a sustained drop of intracellular $\mathrm{K}^{+}$. However, experimental high $\mathrm{K}^{+}$depolarizes the membrane and reduces the membrane potential (typical -40 to $-80 \mathrm{mV}$ ) to near neutrality, and the membrane potential is a critical parameter for much of the eukaryotic biology (173-177). We recently found that both membrane depolarization and hyperpolarization were sufficient to block NLRP3 inflammasome activation without involving large amounts of $\mathrm{K}^{+}$moving across the plasma membrane (our own observations). Therefore, molecular details of $\mathrm{K}^{+}$efflux and NLRP3 inflammasome activation need to be further scrutinized. In addition to $\mathrm{K}^{+}, \mathrm{Ca}^{2+}$ influx is induced by numerous NLRP3 activators (178). $\mathrm{Ca}^{2+}$ influx was suggested to be important for NLRP3 activation since thapsigargin, an inhibitor of the sarcoplasmic/ER $\mathrm{Ca}^{2+}$-ATPase, incubation in $\mathrm{Ca}^{2+}$ free media (179), or BAPTA-AM (intracellular $\mathrm{Ca}^{2+}$ chelator) (180) significantly suppressed NLRP3 inflammasome activation in ATP-stimulated BMDM. Another piece of evidence was the calcium-sensing receptor activation stimulated NLRP3 inflammasome and knockdown of the receptor had the opposite effect (180). However, there are reports arguing against the $\mathrm{Ca}^{2+}$ influx model. One group found that extracellular $\mathrm{Ca}^{2+}$ activated NLRP3 through $\mathrm{K}^{+}$ efflux (151). Another group, on the other hand, suggested that $\mathrm{Ca}^{2+}$ influx was neither necessary nor sufficient for NLRP3 activation during ATP, Nigericin, and LLOMe stimulation (181). In a report aiming to bridge the two ion-dependent models, $\mathrm{K}^{+}$and $\mathrm{Ca}^{2+}$ visualization sensors were used and the results suggested that $\mathrm{K}^{+}$efflux was necessary for sustained $\mathrm{Ca}^{2+}$ influx while $\mathrm{K}^{+}$ efflux was independent of $\mathrm{Ca}^{2+}$ influx (182).

\section{Cell Death}

Many particles with different chemical composition, morphology, size, hydrophobicity, and ionic charge were proved to be cytotoxic. Thus a lot of efforts were made to found a common pathway. Generally, solid particle-induced cell death relies on cellular uptake, indicating that phagosome or lysosome may be important in this type of cell death $(165,183,184)$. Downstream of particle phagocytosis is the lysosome rupture and ROS production, which gives rise to oxidative stress (185-187). Following oxidative stress 
are mitochondrial dysfunction, DNA damage, and protein/lipid oxidation $(185,188)$. These factors work together to induce the eventual cytotoxicity (155). Several additional pathways have been proposed in the literature (Figure 2).

Silica-containing particles are ubiquitous, found in volcanic ashes (189), materials made from quartz and kaolin (190), and dusts (34). Silica dust (nano and crystalline particles) is an environmental and occupational hazard, as observed in construction, mining, ceramics, and foundries industry. This topic has been discussed in several reviews and very well documented clinically (191, 192). Silica has been found to be cytotoxic for a long time and believed to be responsible for silicosis $(158,159)$, and contribute to several types of cancer, infection (such as TB and Salmonella) (193-195) and autoimmune diseases (196). As we discussed earlier, crystalline silica is more potent in inducing alveolar macrophage death than colloidal and amorphous counterparts (34). Signaling-wise silica induced NLRP3 activation in LPS-primed macrophages in vitro (159). Some reports supported the notion that silica induced NLRP3-dependent pyroptosis, which relied on $\mathrm{K}^{+}$efflux and caspase- 1 activation. However, others argued against the dependence on NLRP3 $(151,158,170)$. A report found the reliance on receptor-interacting serine/threonine-protein kinase 3 (RIPK3)-mixed lineage kinase domain-like (MLKL)-driven necroptosis (9) while another group suggested the importance of redundant cathepsins (170). Furthermore, some groups reported that silica promoted cell death via apoptosis through mitochondria damage pathway initiated by oxidative stress $(156,197)$. A slight variation was the proposal suggesting that silica induced both apoptosis and necrosis that depended on the transmembrane potential change of mitochondria. Hyperpolarization induced caspase-3 and 9-mediated apoptosis while depolarization induced no caspase activation during necrosis (198). In addition, using ATP synthesis inhibitors, oligomycin and 2-deoxyglucose, it was observed that decreased ATP level induced NLRP3 activation and necrosis while increased ATP led to apoptosis $(199,200)$. Therefore, crystal-induced cell death may be also under the control of ATP levels. The extreme redundancy in the types of cell death is difficult to comprehend, likely resulting from the different system setups.

Similar to silica, alum has been reported to induce lysosome rupture thus activating NLRP3 inflammasome (126, 127, 165, 201, 202). Cell death, however, was not determined in the majority of those papers except two reported that NLRP3 and caspase-1 deficiencies did not affect alum-induced macrophage cell death $(126,151)$. On the other hand, aluminum oxide nanoparticles were reported to depolarize cell membrane and lead to significant cell death in epithelial cells (203). Lima et al. reported that aluminduced macrophage cell death in vitro was a direct consequence of

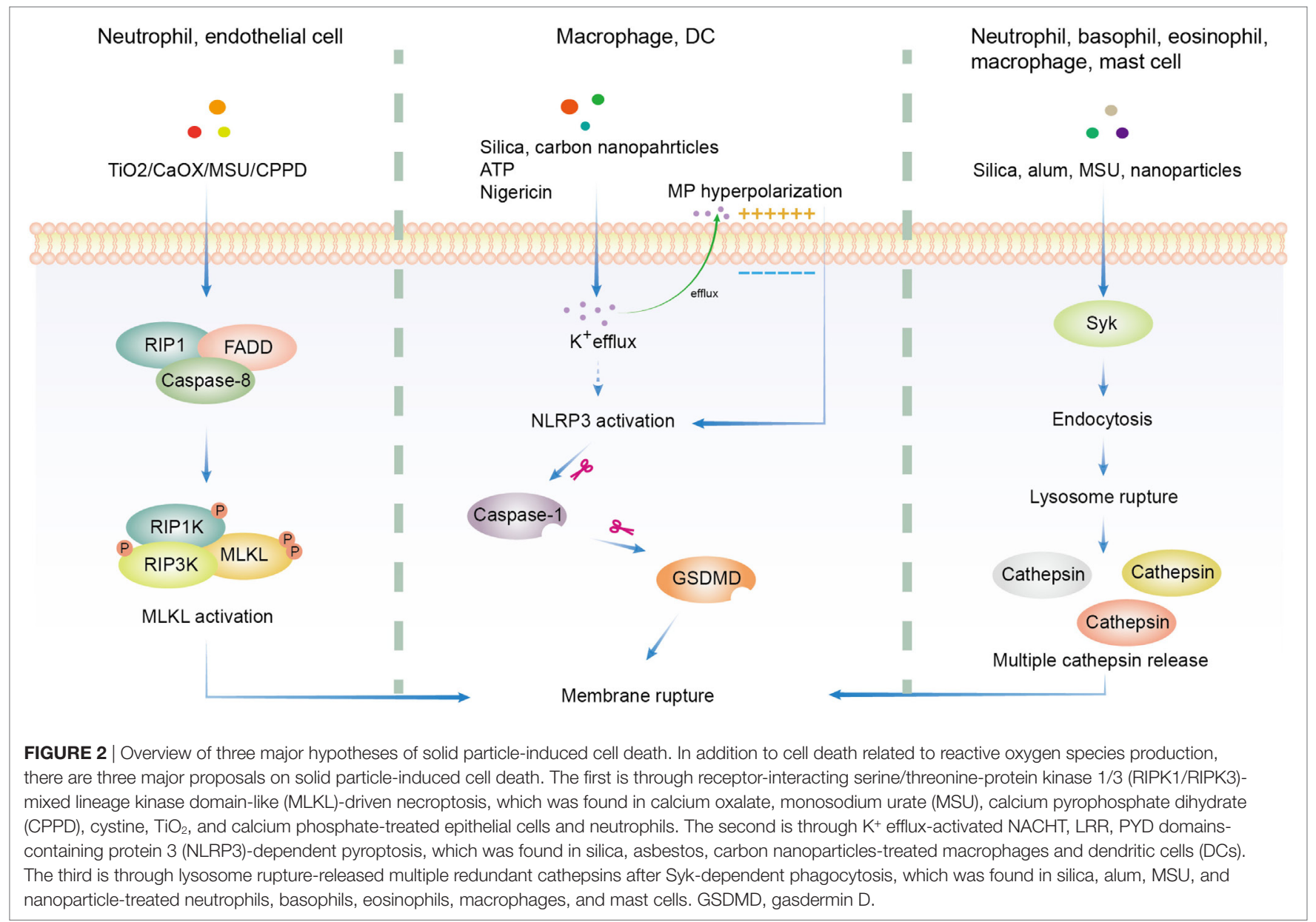


lysosomal membrane rupture without involving NLRP3 signaling cascade (166). Although MSU has been used as a model system for NLRP3 inflammation activation, much less is known about its ability to induce cell death although there is one group found that RIPK1-RIPK3-MLKL signaling pathway may be critical for MSU and other crystals-induced neutrophil extracellular DNA release and cell death (7). MSU was found to induce neutrophil PI3K activation, downstream of Syk and Src family kinases. PI3K is a critical element regulating the degranulation of neutrophils, a mechanism contributing to the pathogenesis of gout (204). As direct membrane binding was believed to be important for MSU-induced Syk activation (69) and NLRP3 inflammasome (167), we made a Syk conditional knock out mouse model and found that Syk deficiency indeed reduced MSU-induced cell death (our own observations). The exact mechanism of how MSU activates Syk and Src pathways thus induces cell death remains unclear.

A lot of metal oxide nanoparticles exhibited cytotoxicity $(40,205,206)$, as did other common nanoparticles, including CNT, Fullerene (207), dental calculus (208), asbestos (36), carbon black nanoparticles (209), and quantum dots (210). The mechanisms of cytotoxicity, however, can be quite different. Most of them were found to induce ROS production that was associated with mitochondrial dysfunction (155). Unlike other particles, quantum dot treatment increased FAS expression and membrane lipid peroxidation that led to the impairment of mitochondria in human neuroblastoma cells (210). In addition, RIPK1-RIPK3-MLKL axis was proven important in human and murine renal tubular cell death induced by $\mathrm{TiO}_{2}$ and calcium oxalate (8). Anders's group reported that MSU, calcium oxalate, CPPD, and cystine crystals mediated cell death of kidney epithelial cells (9) that were blocked by necrostatin-1 (inhibitor of necroptosis). This type of cell death was independent of caspase activation, suggesting that NLRP3 inflammasome activation associated with those crystals was not responsible for their cell death (211). As the most abundant innate immune cells, neutrophils phagocytose large amounts of crystals (212). In doing so, they process a special type of cell death by releasing their own DNA to trap those particles, a program called neutrophil extracellular traps (NET), including MSU, Silica, calcium oxalate, calcium phosphate, and asbestos (7). RIPK1RIPK3-MLKL signaling pathway was found to be critical for this programmed cell death (NETosis) $(7,213)$. NETosis was also observed in eosinophils and basophils upon particle contact (212).

\section{CONCLUDING REMARKS}

Solid particle-mediated cellular responses are an old topic of medicine and becoming more diverse in modern life style. Particulate matters impact us in multiple ways. They represent the latest technologies in vaccine design and cancer therapy.

\section{REFERENCES}

1. Braakhuis HM, Park MV, Gosens I, De Jong WH, Cassee FR. Physicochemical characteristics of nanomaterials that affect pulmonary inflammation. Part Fibre Toxicol (2014) 11:18. doi:10.1186/1743-8977-11-18

2. Kono H, Chen C-J, Ontiveros F, Rock KL. Uric acid promotes an acute inflammatory response to sterile cell death in mice. J Clin Invest (2010) 120:1939-49. doi:10.1172/JCI40124
However, the limitations and disadvantages of using these particles and salt crystals in the development of pharmaceuticals, drugs, bio-therapeutics have not been systematically studied. In environmental exposure studies and some bacterial and viral material-based therapeutic regimens, solid particles are seldom pure, with frequent contamination of endotoxins and microbial nucleic acids. These factors must be carefully investigated. At the other end, crystalline arthropathies remain as much as a health threat as they have throughout the time. While the research on this subject has been multifaceted and increasingly intense, particularly with regard to their signaling pathways, we are far from establishing a framework of understanding how these solid structures are perceived by our cells and whether there are a set of critical events governing their cellular activation. As the variations in the types of particles and host cells involved can be extremely diverse, much work is still ahead. Several issues should be considered with higher priority. One is the signaling events in particulate adjuvants that lead to enhanced immune activation. This is critical because these adjuvants are used in populationbased vaccination and new varieties are coming into clinical tests. New mechanistic insights will certainly benefit the better designs of vaccines. Another important topic is to develop a systematic approach to study the host responses toward nano- and microparticles. The chemical and geometrical properties of those substances have been studied for decades and their signaling events have been one of the leading topics in immunology for 20 years. Thus far, we are in possession of very few consensuses and are often puzzled by conflicting data. One possible approach is to establish a model system with definable variables, such as the work on LDH by Williams et al. (48). This type of work will gradually lead to more mechanistic insights that enable us to better harness the particles that are in contact with our cells.

\section{AUTHOR CONTRIBUTIONS}

YS conceptualized the review and wrote the manuscript except for the inflammasome and the cell death, which were drafted by FS. YS revised the manuscript with assistance from FS.

\section{ACKNOWLEDGMENTS}

We thank Ying Xu for the illustrations. This work was supported by the joint Peking-Tsinghua Center for Life Sciences and grants from the National Natural Science Foundation of China General Program (31370878), Key Program (31630023), and Creative Research Groups Program (81621002), National Institutes of Health (R01AI098995), Natural Sciences and Engineering Research Council of Canada (RGPIN-355350/396037), and Canadian Institutes of Health Research (MOP-119295) to YS.

3. Churg A, Wiggs B. Fiber size and number in amphibole asbestos-induced mesothelioma. Am J Pathol (1984) 115:437-42.

4. Yano E, Wang Z-M, Wang X-R, Wang M-Z, Lan Y-J. Cancer mortality among workers exposed to amphibole-free chrysotile asbestos. Am J Epidemiol (2001) 154:538-43. doi:10.1093/aje/154.6.538

5. Franklin BS, Mangan MS, Latz E. Crystal formation in inflammation. Annu Rev Immunol (2016) 34:173-202. doi:10.1146/annurev-immunol-041015055539 
6. Martinon F, Petrilli V, Mayor A, Tardivel A, Tschopp J. Gout-associated uric acid crystals activate the NALP3 inflammasome. Nature (2006) 440:237-41. doi: $10.1038 /$ nature 04516

7. Desai J, Foresto-Neto O, Honarpisheh M, Steiger S, Nakazawa D, Popper B, et al. Particles of different sizes and shapes induce neutrophil necroptosis followed by the release of neutrophil extracellular trap-like chromatin. Sci Rep (2017) 7:15003. doi:10.1038/s41598-017-15106-0

8. Honarpisheh M, Foresto-Neto O, Desai J, Steiger S, Gómez LA, Popper B, et al. Phagocytosis of environmental or metabolic crystalline particles induces cytotoxicity by triggering necroptosis across a broad range of particle size and shape. Sci Rep (2017) 7:15523. doi:10.1038/s41598-017-15804-9

9. Mulay SR, Desai J, Kumar SV, Eberhard JN, Thomasova D, Romoli S, et al. Cytotoxicity of crystals involves RIPK3-MLKL-mediated necroptosis. Nat Commun (2016) 7:10274. doi:10.1038/ncomms10274

10. Castranova V. Signaling pathways controlling the production of inflammatory mediators in response to crystalline silica exposure: role of reactive oxygen/nitrogen species. Free Radic Biol Med (2004) 37:916-25. doi:10.1016/j. freeradbiomed.2004.05.032

11. Khan SR. Reactive oxygen species, inflammation and calcium oxalate nephrolithiasis. Transl Androl Urol (2014) 3:256-76. doi:10.3978/j.issn.22234683.2014.06.04

12. Apostolico Jde S, Lunardelli VA, Coirada FC, Boscardin SB, Rosa DS. Adjuvants: classification, modus operandi, and licensing. J Immunol Res (2016) 2016:1459394. doi:10.1155/2016/1459394

13. Rock KL, Hearn A, Chen CJ, Shi Y. Natural endogenous adjuvants. Springer Semin Immunopathol (2005) 26:231-46. doi:10.1007/s00281-004-0173-3

14. Flannagan RS, Jaumouille V, Grinstein S. The cell biology of phagocytosis. AnnuRevPathol(2012) 7:61-98. doi:10.1146/annurev-pathol-011811-132445

15. Horie M, Fukui H, Endoh S, Maru J, Miyauchi A, Shichiri M, et al. Comparison of acute oxidative stress on rat lung induced by nano and fine-scale, soluble and insoluble metal oxide particles: $\mathrm{NiO}$ and TiO2. Inhal Toxicol (2012) 24:391-400. doi:10.3109/08958378.2012.682321

16. Pauluhn J. Pulmonary toxicity and fate of agglomerated 10 and $40 \mathrm{~nm}$ aluminum oxyhydroxides following 4 -week inhalation exposure of rats: toxic effects are determined by agglomerated, not primary particle size. Toxicol Sci (2009) 109:152-67. doi:10.1093/toxsci/kfp046

17. Roursgaard M, Poulsen SS, Poulsen LK, Hammer M, Jensen KA, Utsunomiya S, et al. Time-response relationship of nano and micro particle induced lung inflammation. Quartz as reference compound. Hum Exp Toxicol (2010) 29:915-33. doi:10.1177/0960327110363329

18. Wendorf J, Chesko J, Kazzaz J, Ugozzoli M, Vajdy M, O’Hagan D, et al. A comparison of anionic nanoparticles and microparticles as vaccine delivery systems. Hum Vaccin (2008) 4:44-9. doi:10.4161/hv.4.1.4886

19. Shanbhag AS, Jacobs JJ, Black J, Galante JO, Glant TT. Macrophage/particle interactions: effect of size, composition and surface area. J Biomed Mater Res (1994) 28:81-90. doi:10.1002/jbm.820280111

20. Renwick LC, Brown D, Clouter A, Donaldson K. Increased inflammation and altered macrophage chemotactic responses caused by two ultrafine particle types. Occup Environ Med (2004) 61:442-7. doi:10.1136/oem.2003.008227

21. Napierska D, Thomassen LCJ, Rabolli V, Lison D, Gonzalez L, Kirsch-Volders M, et al. Size-dependent cytotoxicity of monodisperse silica nanoparticles in human endothelial cells. Small (2009) 5:846-53. doi:10.1002/smll. 200800461

22. Wottrich R, Diabate S, Krug HF. Biological effects of ultrafine model particles in human macrophages and epithelial cells in mono- and co-culture. Int J Hyg Environ Health (2004) 207:353-61. doi:10.1078/1438-4639-00300

23. Liu W, Wu Y, Wang C, Li HC, Wang T, Liao CY, et al. Impact of silver nanoparticles on human cells: effect of particle size. Nanotoxicology (2010) 4:319-30. doi:10.3109/17435390.2010.483745

24. Kusaka T, Nakayama M, Nakamura K, Ishimiya M, Furusawa E, Ogasawara K. Effect of silica particle size on macrophage inflammatory responses. PLoS One (2014) 9:e92634. doi:10.1371/journal.pone.0092634

25. Morishige T, Yoshioka Y, Inakura H, Tanabe A, Yao X, Tsunoda S, et al. Cytotoxicity of amorphous silica particles against macrophage-like THP-1 cells depends on particle-size and surface properties. Pharmazie (2010) 65:596-9. doi:10.1691/ph.2010.9408

26. Olivier V, Duval J-L, Hindié M, Pouletaut P, Nagel M-D. Comparative particle-induced cytotoxicity toward macrophages and fibroblasts. Cell Biol Toxicol (2003) 19:145-59. doi:10.1023/A:1024723326036
27. Braydich-Stolle LK, Schaeublin NM, Murdock RC, Jiang J, Biswas P, Schlager JJ, et al. Crystal structure mediates mode of cell death in $\mathrm{TiO} 2$ nanotoxicity. J Nanopart Res (2009) 11:1361-74. doi:10.1007/s11051-0089523-8

28. Donaldson K, Murphy FA, Duffin R, Poland CA. Asbestos, carbon nanotubes and the pleural mesothelium: a review of the hypothesis regarding the role of long fibre retention in the parietal pleura, inflammation and mesothelioma. Part Fibre Toxicol (2010) 7:5-5. doi:10.1186/1743-8977-7-5

29. Goodglick LA, Kane AB. Cytotoxicity of long and short crocidolite asbestos fibers in vitro and in vivo. Cancer Res (1990) 50:5153-63.

30. Zhao X, Ng S, Heng BC, Guo J, Ma L, Tan TTY, et al. Cytotoxicity of hydroxyapatite nanoparticles is shape and cell dependent. Arch Toxicol (2013) 87:1037-52. doi:10.1007/s00204-012-0827-1

31. Palomäki J, Välimäki E, Sund J, Vippola M, Clausen PA, Jensen KA, et al. Long, needle-like carbon nanotubes and asbestos activate the NLRP3 inflammasome through a similar mechanism. ACS Nano (2011) 5:6861-70. doi:10.1021/nn200595c

32. Porter DW, Wu N, Hubbs AF, Mercer RR, Funk K, Meng F, et al. Differential mouse pulmonary dose and time course responses to titanium dioxide nanospheres and nanobelts. Toxicol Sci (2013) 131:179-93. doi:10.1093/ toxsci/kfs261

33. Menas AL, Yanamala N, Farcas MT, Russo M, Friend S, Fournier PM, et al. Fibrillar vs crystalline nanocellulose pulmonary epithelial cell responses: cytotoxicity or inflammation? Chemosphere (2017) 171:671-80. doi:10.1016/j. chemosphere.2016.12.105

34. Warheit DB, McHugh TA, Hartsky MA. Differential pulmonary responses in rats inhaling crystalline, colloidal or amorphous silica dusts. Scand J Work Environ Health (1995) 21:19-21.

35. Sandberg WJ, Låg M, Holme JA, Friede B, Gualtieri M, Kruszewski M, et al. Comparison of non-crystalline silica nanoparticles in IL-1 $\beta$ release from macrophages. Part Fibre Toxicol (2012) 9:32. doi:10.1186/1743-8977-9-32

36. Brunner TJ, Wick P, Manser P, Spohn P, Grass RN, Limbach LK, et al. In vitro cytotoxicity of oxide nanoparticles: comparison to asbestos, silica, and the effect of particle solubility. Environ Sci Technol (2006) 40:4374-81. doi:10.1021/es052069i

37. Carter JD, Ghio AJ, Samet JM, Devlin RB. Cytokine production by human airway epithelial cells after exposure to an air pollution particle is metal-dependent. Toxicol Appl Pharmacol (1997) 146:180-8. doi:10.1006/ taap.1997.8254

38. Cho WS, Duffin R, Howie SE, Scotton CJ, Wallace WA, Macnee W, et al. Progressive severe lung injury by zinc oxide nanoparticles; the role of $\mathrm{Zn} 2+$ dissolution inside lysosomes. Part Fibre Toxicol (2011) 8:27. doi:10.1186/ 1743-8977-8-27

39. Cho WS, Duffin R, Thielbeer F, Bradley M, Megson IL, Macnee W, et al. Zeta potential and solubility to toxic ions as mechanisms of lung inflammation caused by metal/metal oxide nanoparticles. Toxicol Sci (2012) 126:469-77. doi:10.1093/toxsci/kfs006

40. Fahmy B, Cormier SA. Copper oxide nanoparticles induce oxidative stress and cytotoxicity in airway epithelial cells. Toxicol In Vitro (2009) 23:1365-71. doi:10.1016/j.tiv.2009.08.005

41. Gojova A, Guo B, Kota RS, Rutledge JC, Kennedy IM, Barakat AI. Induction of inflammation in vascular endothelial cells by metal oxide nanoparticles: effect of particle composition. Environ Health Perspect (2007) 115:403-9. doi:10.1289/ehp.8497

42. Arts JH, Muijser H, Duistermaat E, Junker K, Kuper CF. Five-day inhalation toxicity study of three types of synthetic amorphous silicas in Wistar rats and post-exposure evaluations for up to 3 months. Food Chem Toxicol (2007) 45:1856-67. doi:10.1016/j.fct.2007.04.001

43. Choi HS, Ashitate Y, Lee JH, Kim SH, Matsui A, Insin N, et al. Rapid translocation of nanoparticles from the lung airspaces to the body. Nat Biotechnol (2010) 28:1300-3. doi:10.1038/nbt.1696

44. Reuzel PG, Bruijntjes JP, Feron VJ, Woutersen RA. Subchronic inhalation toxicity of amorphous silicas and quartz dust in rats. Food Chem Toxicol (1991) 29:341-54. doi:10.1016/0278-6915(91)90205-L

45. Morishige T, Yoshioka Y, Inakura H, Tanabe A, Yao X, Narimatsu S, et al. The effect of surface modification of amorphous silica particles on NLRP3 inflammasome mediated IL-1 $\beta$ production, ROS production and endosomal rupture. Biomaterials (2010) 31:6833-42. doi:10.1016/j. biomaterials.2010.05.036 
46. Drescher D, Orts-Gil G, Laube G, Natte K, Veh RW, Österle W, et al. Toxicity of amorphous silica nanoparticles on eukaryotic cell model is determined by particle agglomeration and serum protein adsorption effects. Anal Bioanal Chem (2011) 400:1367. doi:10.1007/s00216-011-4893-7

47. Tomazic-Jezic VJ, Merritt K, Umbreit TH. Significance of the type and the size of biomaterial particles on phagocytosis and tissue distribution. J Biomed Mater Res (2001) 55:523-9. doi:10.1002/1097-4636(20010615) 55:4<523::AID-JBM1045>3.0.CO;2-G

48. Williams GR, Fierens K, Preston SG, Lunn D, Rysnik O, De Prijck S, et al. Immunity induced by a broad class of inorganic crystalline materials is directly controlled by their chemistry. JExp Med (2014) 211:1019-25. doi:10.1084/jem.20131768

49. Ichida K, Amaya Y, Okamoto K, Nishino T. Mutations associated with functional disorder of xanthine oxidoreductase and hereditary xanthinuria in humans. Int J Mol Sci (2012) 13:15475-95. doi:10.3390/ijms131115475

50. Chillarón J, Font-Llitjós M, Fort J, Zorzano A, Goldfarb DS, Nunes V, et al. Pathophysiology and treatment of cystinuria. Nat Rev Nephrol (2010) 6:424. doi:10.1038/nrneph.2010.69

51. Bollée G, Harambat J, Bensman A, Knebelmann B, Daudon M, CeballosPicot I. Adenine phosphoribosyltransferase deficiency. Clin J Am Soc Nephrol (2012) 7:1521-7. doi:10.2215/CJN.02320312

52. Ceballos-PicotI,Daudon M,HarambatJ,Bensman A, Knebelmann B, BolleeG. 2,8-Dihydroxyadenine urolithiasis: a not so rare inborn error of purine metabolism. Nucleosides Nucleotides Nucleic Acids (2014) 33:241-52. doi:10.1080/15257770.2013.853780

53. Evan AP, Bledsoe SB, Connors BA, Deng L, Liang L, Shao C, et al. Sequential analysis of kidney stone formation in the APRT knockout mouse. Kidney Int (2001) 60:910-23. doi:10.1046/j.1523-1755.2001.060003910.x

54. Nasr SH, Sethi S, Cornell LD, Milliner DS, Boelkins M, Broviac J, et al. Crystalline nephropathy due to 2,8-dihydroxyadeninuria: an underrecognized cause of irreversible renal failure. Nephrol Dial Transplant (2010) 25:1909-15. doi:10.1093/ndt/gfp711

55. Nuki G, Simkin PA. A concise history of gout and hyperuricemia and their treatment. Arthritis Res Ther (2006) 8:S1. doi:10.1186/ar1906

56. Dunn JP, Brooks GW, Mausner J, Rodnan GP, Cobb S. Social class gradient of serum uric acid levels in males. JAMA (1963) 185:431-6. doi:10.1001/ jama.1963.03060060029012

57. Wilcox WR, Khalaf AA. Nucleation of monosodium urate crystals. Ann Rheum Dis (1975) 34:332-9. doi:10.1136/ard.34.4.332

58. Kanevets U, Sharma K, Dresser K, Shi Y. A role of IgM antibodies in monosodium urate crystal formation and associated adjuvanticity. J Immunol (2009) 182:1912-8. doi:10.4049/jimmunol.0803777

59. Kam M, Perl-Treves D, Caspi D, Addadi L. Antibodies against crystals. FASEB J (1992) 6:2608-13. doi:10.1096/fasebj.6.8.1592211

60. Cherian PV, Schumacher HR Jr. Immunochemical and ultrastructural characterization of serum proteins associated with monosodium urate crystals (MSU) in synovial fluid cells from patients with gout. Ultrastruct Pathol (1986) 10:209-19. doi:10.3109/01913128609032219

61. Kozin F, McCarty DJ. Molecular orientation of immunoglobulin G adsorbed to microcrystalline monosodium urate monohydrate. J Lab Clin Med (1980) 95:49-58.

62. Barabe F, Gilbert C, Liao N, Bourgoin SG, Naccache PH. Crystal-induced neutrophil activation VI. Involvment of FcgammaRIIIB (CD16) and CD11b in response to inflammatory microcrystals. FASEB J (1998) 12:209-20. doi:10.1096/fasebj.12.2.209

63. Desaulniers P, Fernandes M, Gilbert C, Bourgoin SG, Naccache PH. Crystalinduced neutrophil activation. VII. Involvement of Syk in the responses to monosodium urate crystals. J Leukoc Biol (2001) 70:659-68. doi:10.1189/ jlb.70.4.659

64. Liu-Bryan R, Pritzker K, Firestein GS, Terkeltaub R. TLR2 signaling in chondrocytes drives calcium pyrophosphate dihydrate and monosodium urate crystal-induced nitric oxide generation. J Immunol (2005) 174:5016-23. doi:10.4049/jimmunol.174.8.5016

65. Liu-Bryan R, Scott P, Sydlaske A, Rose DM, Terkeltaub R. Innate immunity conferred by toll-like receptors 2 and 4 and myeloid differentiation factor 88 expression is pivotal to monosodium urate monohydrate crystal-induced inflammation. Arthritis Rheum (2005) 52:2936-46. doi:10.1002/art.21238
66. Scott P, Ma H, Viriyakosol S, Terkeltaub R, Liu-Bryan R. Engagement of CD14 mediates the inflammatory potential of monosodium urate crystals. J Immunol (2006) 177:6370-8. doi:10.4049/jimmunol.177.9.6370

67. Chen CJ, Shi Y, Hearn A, Fitzgerald K, Golenbock D, Reed G, et al. MyD88dependent IL-1 receptor signaling is essential for gouty inflammation stimulated by monosodium urate crystals. J Clin Invest (2006) 116:2262-71. doi:10.1172/JCI28075

68. Neumann K, Castiñeiras-Vilariño $M$, Höckendorf U, Hannesschläger $N$, Lemeer S, Kupka D, et al. Clec12a is an inhibitory receptor for uric acid crystals that regulates inflammation in response to cell death. Immunity (2014) 40:389-99. doi:10.1016/j.immuni.2013.12.015

69. Ng G, Sharma K, Ward SM, Desrosiers MD, Stephens LA, Schoel WM, et al. Receptor-independent, direct membrane binding leads to cell-surface lipid sorting and Syk kinase activation in dendritic cells. Immunity (2008) 29:807-18. doi:10.1016/j.immuni.2008.09.013

70. Swan A, Dularay B, Dieppe P. A comparison of the effects of urate, hydroxyapatite and diamond crystals on polymorphonuclear cells: relationship of mediator release to the surface area and adsorptive capacity of different particles. J Rheumatol (1990) 17:1346-52.

71. Mandel NS, Mandel GS, Carroll DJ, Halverson PB. Calcium pyrophosphate crystal deposition. An in vitro study using a gelatin matrix model. Arthritis Rheum (1984) 27:789-96. doi:10.1002/art.1780270710

72. Costello JC, Rosenthal AK, Kurup IV, Masuda I, Medhora M, Ryan LM. Parallel regulation of extracellular ATP and inorganic pyrophosphate: roles of growth factors, transduction modulators, and ANK. Connect Tissue Res (2011) 52:139-46. doi:10.3109/03008207.2010.491928

73. Ryan LM, McCarty DJ. Understanding inorganic pyrophosphate metabolism: toward prevention of calcium pyrophosphate dihydrate crystal deposition. Ann Rheum Dis (1995) 54:939-41. doi:10.1136/ard.54.12.939

74. Schumacher HR. The role of inflammation and crystals in the pain of osteoarthritis. Semin Arthritis Rheum (1989) 18:81-5. doi:10.1016/0049-0172(89) 90022-X

75. Rosenthal AK, Ryan LM. Calcium pyrophosphate deposition disease. N Engl J Med (2016) 374:2575-84. doi:10.1056/NEJMra1511117

76. Ea HK, Uzan B, Rey C, Liote F. Octacalcium phosphate crystals directly stimulate expression of inducible nitric oxide synthase through p38 and JNK mitogen-activated protein kinases in articular chondrocytes. Arthritis Res Ther (2005) 7:R915-26. doi:10.1186/ar1763

77. McCarthy G, Westfall P, Masuda I, Christopherson P, Cheung H, Mitchell P. Basic calcium phosphate crystals activate human osteoarthritic synovial fibroblasts and induce matrix metalloproteinase-13 (collagenase-3) in adult porcine articular chondrocytes. Ann Rheum Dis (2001) 60:399-406. doi:10.1136/ard.60.4.399

78. Higo T, Duronio V, Tudan C, Burt HM, Jackson JK. Calcium pyrophosphate dihydrate crystal-induced inhibition of neutrophil apoptosis: involvement of Bcl-2 family members. Inflamm Res (2010) 59:71-81. doi:10.1007/ s00011-009-0073-z

79. Lammert F, Gurusamy K, Ko CW, Miquel J-F, éndez-Sánchez NM, Portincasa P, et al. Gallstones. Nat Rev Dis Primers (2016) 2:16024. doi:10.1038/nrdp.2016.24

80. Buhaescu I, Izzedine H. Mevalonate pathway: a review of clinical and therapeutical implications. Clin Biochem (2007) 40:575-84. doi:10.1016/j. clinbiochem.2007.03.016

81. Simons K, Ikonen E. How cells handle cholesterol. Science (2000) 290:1721-6. doi:10.1126/science.290.5497.1721

82. Moore KJ, Tabas I. Macrophages in the pathogenesis of atherosclerosis. Cell (2011) 145:341-55. doi:10.1016/j.cell.2011.04.005

83. Abela GS. Cholesterol crystals piercing the arterial plaque and intima trigger local and systemic inflammation. JClin Lipidol (2010) 4:156-64. doi:10.1016/j.jacl.2010.03.003

84. Abela GS, Aziz K. Cholesterol crystals cause mechanical damage to biological membranes: a proposed mechanism of plaque rupture and erosion leading to arterial thrombosis. Clin Cardiol (2005) 28:413-20. doi:10.1002/ clc.4960280906

85. Björkegren JLM, Hägg S, Talukdar HA, Foroughi Asl H, Jain RK, Cedergren C, et al. Plasma cholesterol-induced lesion networks activated before regression of early, mature, and advanced atherosclerosis. PLoS Genet (2014) 10:e1004201. doi:10.1371/journal.pgen.1004201 
86. Duewell P, Kono H, Rayner KJ, Sirois CM, Vladimer G, Bauernfeind FG, et al. NLRP3 inflammasomes are required for atherogenesis and activated by cholesterol crystals. Nature (2010) 464:1357-61. doi:10.1038/nature08938

87. Liu L, Gardecki JA, Nadkarni SK, Toussaint JD, Yagi Y, Bouma BE, et al. Imaging the subcellular structure of human coronary atherosclerosis using micro-optical coherence tomography. Nat Med (2011) 17:1010-4. doi:10.1038/nm.2409

88. Lim RS, Suhalim JL, Miyazaki-Anzai S, Miyazaki M, Levi M, Potma EO, et al. Identification of cholesterol crystals in plaques of atherosclerotic mice using hyperspectral CARS imaging. J Lipid Res (2011) 52:2177-86. doi:10.1194/jlr.M018077

89. Baumer Y, McCurdy S, Weatherby TM, Mehta NN, Halbherr S, Halbherr P, et al. Hyperlipidemia-induced cholesterol crystal production by endothelial cells promotes atherogenesis. Nat Commun (2017) 8:1129. doi:10.1038/ s41467-017-01186-z

90. Hansson GK, Hermansson A. The immune system in atherosclerosis. Nat Immunol (2011) 12:204-12. doi:10.1038/ni.2001

91. Hammerschmidt DE, Greenberg CS, Yamada O, Craddock PR, Jacob HS. Cholesterol and atheroma lipids activate complement and stimulate granulocytes. A possible mechanism for amplification of ischemic injury in atherosclerotic states. J Lab Clin Med (1981) 98:68-77.

92. Samstad EO, Niyonzima N, Nymo S, Aune MH, Ryan L, Bakke SS, et al. Cholesterol crystals induce complement-dependent inflammasome activation and cytokine release. J Immunol (2014) 192:2837-45. doi:10.4049/ jimmunol.1302484

93. Freigang S, Ampenberger F, Weiss A, Kanneganti TD, Iwakura Y, Hersberger M, et al. Fatty acid-induced mitochondrial uncoupling elicits inflammasome-independent IL-1alpha and sterile vascular inflammation in atherosclerosis. Nat Immunol (2013) 14:1045-53. doi:10.1038/ni.2704

94. Sjogren U, Mukohyama H, Roth C, Sundqvist G, Lerner UH. Boneresorbing activity from cholesterol-exposed macrophages due to enhanced expression of interleukin-1alpha. J Dent Res (2002) 81:11-6. doi:10.1177/ 002203450208100104

95. Rajamäki K, Lappalainen J, Öörni K, Välimäki E, Matikainen S, Kovanen PT, et al. Cholesterol crystals activate the NLRP3 inflammasome in human macrophages: a novel link between cholesterol metabolism and inflammation. PLoS One (2010) 5:e11765. doi:10.1371/journal.pone.0011765

96. Menu P, Pellegrin M, Aubert J, Bouzourene K, Tardivel A, Mazzolai L, et al. Atherosclerosis in ApoE-deficient mice progresses independently of the NLRP3 inflammasome. Cell Death Dis (2011) 2:e137. doi:10.1038/cddis.2011.18

97. Pandey AV, Tekwani BL. Formation of haemozoin/beta-haematin under physiological conditions is not spontaneous. FEBS Lett (1996) 393:189-93. doi:10.1016/0014-5793(96)00881-2

98. Davis SP, Amrein M, Gillrie MR, Lee K, Muruve DA, Ho M. Plasmodium falciparum-induced CD36 clustering rapidly strengthens cytoadherence via p130CAS-mediated actin cytoskeletal rearrangement. FASEB J (2012) 26:1119-30. doi:10.1096/fi.11-196923

99. Gillrie MR, Krishnegowda G, Lee K, Buret AG, Robbins SM, Looareesuwan S, et al. Src-family kinase dependent disruption of endothelial barrier function by Plasmodium falciparum merozoite proteins. Blood (2007) 110:3426-35. doi:10.1182/blood-2007-04-084582

100. Shio MT, Kassa FA, Bellemare M-J, Olivier M. Innate inflammatory response to the malarial pigment hemozoin. Microb Infect (2010) 12:889-99. doi:10.1016/j.micinf.2010.07.001

101. Deroost K, Lays N, Pham T-T, Baci D, Van den Eynde K, Komuta M, et al. Hemozoin induces hepatic inflammation in mice and is differentially associated with liver pathology depending on the Plasmodium strain. PLoS One (2014) 9:e113519. doi:10.1371/journal.pone.0113519

102. Klonis N, Dilanian R, Hanssen E, Darmanin C, Streltsov V, Deed S, et al. Hematin-hematin self-association states involved in the formation and reactivity of the malaria parasite pigment, hemozoin. Biochemistry (2010) 49:6804-11. doi:10.1021/bi100567j

103. Ho M, Webster HK. Immunology of human malaria. A cellular perspective. Parasite Immunol (1989) 11:105-16. doi:10.1111/j.1365-3024.1989. tb00652.x

104. Nguyen PH, Day N, Pram TD, Ferguson DJ, White NJ. Intraleucocytic malaria pigment and prognosis in severe malaria. Trans $\mathrm{R}$ Soc Trop Med Hyg (1995) 89:200-4. doi:10.1016/0035-9203(95)90496-4

105. Pichyangkul S, Saengkrai P, Webster HK. Plasmodium falciparum pigment induces monocytes to release high levels of tumor necrosis factor-alpha and interleukin-1 beta. Am J Trop Med Hyg (1994) 51:430-5. doi:10.4269/ ajtmh.1994.51.430

106. Jaramillo M, Plante I, Ouellet N, Vandal K, Tessier PA, Olivier M. Hemozoininducible proinflammatory events in vivo: potential role in malaria infection. J Immunol (2004) 172:3101-10. doi:10.4049/jimmunol.172.5.3101

107. Jaramillo M, Gowda DC, Radzioch D, Olivier M. Hemozoin increases IFN- $\gamma$-inducible macrophage nitric oxide generation through extracellular

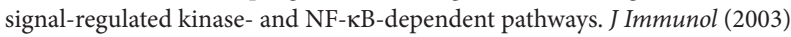
171:4243-53. doi:10.4049/jimmunol.171.8.4243

108. Olivier M, Van Den Ham K, Shio MT, Kassa FA, Fougeray S. Malarial pigment hemozoin and the innate inflammatory response. Front Immunol (2014) 5:25. doi:10.3389/fimmu.2014.00025

109. Coban C, Ishii KJ, Kawai T, Hemmi H, Sato S, Uematsu S, et al. Toll-like receptor 9 mediates innate immune activation by the malaria pigment hemozoin. J Exp Med (2005) 201:19-25. doi:10.1084/jem.20041836

110. Griffith JW, Sun T, McIntosh MT, Bucala R. Pure hemozoin is inflammatory in vivo and activates the NALP3 inflammasome via release of uric acid. J Immunol (2009) 183:5208-20. doi:10.4049/jimmunol.0713552

111. Parroche P, Lauw FN, Goutagny N, Latz E, Monks BG, Visintin A, et al. Malaria hemozoin is immunologically inert but radically enhances innate responses by presenting malaria DNA to toll-like receptor 9. Proc Natl Acad Sci U S A (2007) 104:1919-24. doi:10.1073/pnas.0608745104

112. Wu X, Gowda NM, Kumar S, Gowda DC. Protein-DNA complex is the exclusive malaria parasite component that activates dendritic cells and triggers innate immune responses. J Immunol (2010) 184:4338-48. doi:10.4049/ jimmunol.0903824

113. Tiemi Shio M, Eisenbarth SC, Savaria M, Vinet AF, Bellemare M-J, Harder KW, et al. Malarial hemozoin activates the NLRP3 inflammasome through Lyn and Syk kinases. PLoS Pathog (2009) 5:e1000559. doi:10.1371/journal. ppat.1000559

114. McKee AS, Munks MW, Marrack P. How do adjuvants work? Important considerations for bew generation adjuvants. Immunity (2007) 27:687-90. doi:10.1016/j.immuni.2007.11.003

115. Wen Y, Shi Y. Alum: an old dog with new tricks. Emerg Microbes Infect (2016) 5:e25. doi:10.1038/emi.2016.40

116. Glenny AT, Buttle GAH, Muriel FS. Rate of disappearance of diphtheria toxoid injected into rabbits and guinea - pigs: toxoid precipitated with alum. J Pathol Bacteriol (1931) 34:267-75. doi:10.1002/path.1700340214

117. Glenny AT, Pope CG, Hilda W, Wallace U. Immunological notes. XVII. The antigenic value of toxoid precipitated by potassium alum. J Path Bac (1926) 29:31-40. doi:10.1002/path.1700290106

118. Maschmann E, Küster E, Fischer W. Über die Fähigkeit des TonerdePräparates B, Diphtherie-Toxin zu adsorbieren. Berichte der deutschen chemischen Gesellschaft (1931) 64:2174-8. doi:10.1002/cber.19310640851

119. Gupta R, Rost BE. Aluminum compounds as vaccine adjuvants. Vaccine Adjuvants: Preparation Methods and Research Protocols (2000) 65-89. doi:10.1385/1-59259-083-7:65

120. Murphy K, Weaver C. Janeway's Immunobiology. 9th Edition. New York; London: Garland Science (2016).

121. Holt LB. Developments in Diphtheria Prophylaxis. London: Heinemann (1950). xvi,181 p.

122. Hutchison S, Benson RA, Gibson VB, Pollock AH, Garside P, Brewer JM. Antigen depot is not required for alum adjuvanticity. FASEB J (2012) 26:1272-9. doi:10.1096/fj.11-184556

123. White RG, Coons AH, Connolly JM. Studies on antibody production. III The alum granuloma. J Exp Med (1955) 102:73-82.

124. Jordan MB, Mills DM, Kappler J, Marrack P, Cambier JC. Promotion of B cell immune responses via an alum-induced myeloid cell population. Science (2004) 304:1808-10. doi:10.1126/science.1089926

125. McKee AS, MacLeod M, White J, Crawford F, Kappler JW, Marrack P. Gr1+IL-4-producing innate cells are induced in response to Th2 stimuli and suppress Th1-dependent antibody responses. Int Immunol (2008) 20:659-69. doi:10.1093/intimm/dxn025

126. Eisenbarth SC, Colegio OR, O'Connor W, Sutterwala FS, Flavell RA. Crucial role for the Nalp3 inflammasome in the immunostimulatory properties of aluminium adjuvants. Nature (2008) 453:1122. doi:10.1038/nature06939

127. Kool M, Pétrilli V, De Smedt T, Rolaz A, Hammad H, van Nimwegen M, et al. Cutting edge: alum adjuvant stimulates inflammatory dendritic cells through activation of the NALP3 inflammasome. J Immunol (2008) 181:3755-9. doi:10.4049/jimmunol.181.6.3755 
128. Flach TL, Ng G, Hari A, Desrosiers MD, Zhang P, Ward SM, et al. Alum interaction with dendritic cell membrane lipids is essential for its adjuvanticity. Nat Med (2011) 17:479-87. doi:10.1038/nm.2306

129. Franchi L, Nunez G. The Nlrp3 inflammasome is critical for aluminium hydroxide-mediated IL-1beta secretion but dispensable for adjuvant activity. Eur J Immunol (2008) 38:2085-9. doi:10.1002/eji.200838549

130. McKee AS, Munks MW, MacLeod MK, Fleenor CJ, Van Rooijen N, Kappler JW, et al. Alum induces innate immune responses through macrophage and mast cell sensors, but these sensors are not required for alum to act as an adjuvant for specific immunity. J Immunol (2009) 183:4403-14. doi:10.4049/jimmunol.0900164

131. McKee AS, Burchill MA, Munks MW, Jin L, Kappler JW, Friedman RS, et al. Host DNA released in response to aluminum adjuvant enhances MHC class II-mediated antigen presentation and prolongs $\mathrm{CD} 4 \mathrm{~T}$-cell interactions with dendritic cells. Proc Natl Acad Sci U S A (2013) 110:E1122-31. doi:10.1073/ pnas. 1300392110

132. Thomas M, Keiichi O, Denis B, Claire M, Catherine S, Kouji K, et al. DNA released from dying host cells mediates aluminum adjuvant activity. Nat Med (2011) 17:996-1002. doi:10.1038/nm.2403

133. Noges LE, White J, Cambier JC, Kappler JW, Marrack P. Contamination of DNase preparations confounds analysis of the role of DNA in alum adjuvanted vaccines. J Immunol (2016) 197:1221-30. doi:10.4049/jimmunol.1501565

134. Shi Y, Evans JE, Rock KL. Molecular identification of a danger signal that alerts the immune system to dying cells. Nature (2003) 425:516-21. doi:10.1038/nature01991

135. Wang Y, Ma X, Su C, Peng B, Du J, Jia H, et al. Uric acid enhances the antitumor immunity of dendritic cell-based vaccine. Sci Rep (2015) 5:16427. doi:10.1038/srep16427

136. Kool M, Monique AM, Willart M, van Nimwegen I, Bergen P, Pouliot JC, et al. An unexpected role for uric acid as an inducer of $\mathrm{T}$ helper 2 cell immunity to inhaled antigens and inflammatory mediator of allergic asthma. Immunity (2011) 34:527-40. doi:10.1016/j.immuni.2011.03.015

137. Shi Y, Galusha SA, Rock KL. Cutting edge: elimination of an endogenous adjuvant reduces the activation of CD8 T lymphocytes to transplanted cells and in an autoimmune diabetes model. J Immunol (2006) 176:3905-8. doi:10.4049/jimmunol.176.7.3905

138. Kool M, Soullié T, van Nimwegen M, Willart MAM, Muskens F, Jung S, et al. Alum adjuvant boosts adaptive immunity by inducing uric acid and activating inflammatory dendritic cells. J Exp Med (2008) 205:869-82. doi:10.1084/ jem. 20071087

139. Cimica V, Galarza JM. Adjuvant formulations for virus-like particle (VLP) based vaccines. Clin Immunol (2017) 183:99-108. doi:10.1016/j.clim.2017.08.004

140. Bachmann MF, Jennings GT. Vaccine delivery: a matter of size, geometry, kinetics and molecular patterns. Nat Rev Immunol (2010) 10:787. doi:10.1038/ nri2868

141. Mohsen MO, Zha L, Cabral-Miranda G, Bachmann MF. Major findings and recent advances in virus-like particle (VLP)-based vaccines. Semin Immunol (2017) 34:123-32. doi:10.1016/j.smim.2017.08.014

142. Link A, Zabel F, Schnetzler Y, Titz A, Brombacher F, Bachmann MF. Innate immunity mediates follicular transport of particulate but not soluble protein antigen. J Immunol (2012) 188:3724-33. doi:10.4049/jimmunol.1103312

143. Pavot V, Berthet M, Rességuier J, Legaz S, Handké N, Gilbert SC, et al. Poly(lactic acid) and poly(lactic-co-glycolic acid) particles as versatile carrier platforms for vaccine delivery. Nanomedicine (2014) 9:2703-18. doi:10.2217/ nnm.14.156

144. Fifis T, Gamvrellis A, Crimeen-Irwin B, Pietersz GA, Li J, Mottram PL, et al. Size-dependent immunogenicity: therapeutic and protective properties of nano-vaccines against tumors. J Immunol (2004) 173:3148-54. doi:10.4049/ jimmunol.173.5.3148

145. Silva JM, Vandermeulen G, Oliveira VG, Pinto SN, Rodrigues C, Salgado A, et al. Development of functionalized nanoparticles for vaccine delivery to dendritic cells: a mechanistic approach. Nanomedicine (2014) 9:2639-56. doi: $10.2217 / \mathrm{nnm} .14 .135$

146. Slutter B, Soema PC, Ding Z, Verheul R, Hennink W, Jiskoot W. Conjugation of ovalbumin to trimethyl chitosan improves immunogenicity of the antigen. J Control Release (2010) 143:207-14. doi:10.1016/j.jconrel.2010.01.007

147. Rice-Ficht AC, Arenas-Gamboa AM, Kahl-McDonagh MM, Ficht TA. Polymeric particles in vaccine delivery. Curr Opin Microbiol (2010) 13:106-12. doi:10.1016/j.mib.2009.12.001
148. Thomasin C, Corradin G, Men Y, Merkle HP, Gander B. Tetanus toxoid and synthetic malaria antigen containing poly(lactide)/poly(lactideco-glycolide) microspheres: importance of polymer degradation and antigen release for immune response. J Control Release (1996) 41:131-45. doi:10.1016/0168-3659(96)01363-6

149. Speiser DE, Schwarz K, Baumgaertner P, Manolova V, Devevre E, Sterry W, et al. Memory and effector CD8 T-cell responses after nanoparticle vaccination of melanoma patients. J Immunother (2010) 33:848-58. doi:10.1097/ CJI.0b013e3181f1d614

150. Franchi L, Munoz-Planillo R, Nunez G. Sensing and reacting to microbes through the inflammasomes. Nat Immunol (2012) 13:325-32. doi:10.1038/ ni.2231

151. Muñoz-Planillo R, Kuffa P, Martinez-Colon G, Smith BL, Rajendiran TM, Nunez G. $\mathrm{K}(+)$ efflux is the common trigger of NLRP3 inflammasome activation by bacterial toxins and particulate matter. Immunity (2013) 38:1142-53. doi:10.1016/j.immuni.2013.05.016

152. Schieber M, Chandel NS. ROS function in redox signaling and oxidative stress. Curr Biol (2014) 24:R453-62. doi:10.1016/j.cub.2014.03.034

153. Kaminski MM, Roth D, Krammer PH, Gulow K. Mitochondria as oxidative signaling organelles in T-cell activation: physiological role and pathological implications. Arch Immunol Ther Exp (Warsz) (2013) 61:367-84. doi:10.1007/ s00005-013-0235-0

154. West AP, Shadel GS, Ghosh S. Mitochondria in innate immune responses. Nat Rev Immunol (2011) 11:389-402. doi:10.1038/nri2975

155. Manke A, Wang L, Rojanasakul Y. Mechanisms of nanoparticle-induced oxidative stress and toxicity. Biomed Res Int (2013) 2013:15. doi:10.1155/ 2013/942916

156. Thibodeau M, Giardina C, Hubbard AK. Silica-induced caspase activation in mouse alveolar macrophages is dependent upon mitochondrial integrity and aspartic proteolysis. Toxicol Sci (2003) 76:91-101. doi:10.1093/toxsci/kfg178

157. Zhou R, Yazdi AS, Menu P, Tschopp J. A role for mitochondria in NLRP3 inflammasome activation. Nature (2010) 469:221. doi:10.1038/nature09663

158. Cassel SL, Eisenbarth SC, Iyer SS, Sadler JJ, Colegio OR, Tephly LA, et al. The Nalp3 inflammasome is essential for the development of silicosis. Proc Natl Acad Sci U S A (2008) 105:9035-40. doi:10.1073/pnas.0803933105

159. Dostert C, Pétrilli V, Van Bruggen R, Steele C, Mossman BT, Tschopp J. Innate immune activation through Nalp3 inflammasome sensing of asbestos and silica. Science (2008) 320:674-7. doi:10.1126/science.1156995

160. Dostert C, Guarda G, Romero JF, Menu P, Gross O, Tardivel A, et al. Malarial hemozoin is a Nalp3 inflammasome activating danger signal. PLoS One (2009) 4:e6510. doi:10.1371/journal.pone.0006510

161. Brown DI, Griendling KK. Nox proteins in signal transduction. Free Radic Biol Med (2009) 47:1239-53. doi:10.1016/j.freeradbiomed.2009.07.023

162. Meissner F, Molawi K, Zychlinsky A. Superoxide dismutase 1 regulates caspase-1 and endotoxic shock. Nat Immunol (2008) 9:866-72. doi:10.1038/ ni. 1633

163. Meissner F, Seger RA, Moshous D, Fischer A, Reichenbach J, Zychlinsky A. Inflammasome activation in NADPH oxidase defective mononuclear phagocytes from patients with chronic granulomatous disease. Blood (2010) 116:1570-3. doi:10.1182/blood-2010-01-264218

164. Brojatsch J, Lima H, Kar AK, Jacobson LS, Muehlbauer SM, Chandran K, et al. A proteolytic cascade controls lysosome rupture and necrotic cell death mediated by lysosome-destabilizing adjuvants. PLoS One (2014) 9:e95032. doi:10.1371/journal.pone.0095032

165. Hornung V, Bauernfeind F, Halle A, Samstad EO, Kono H, Rock KL, et al. Silica crystals and aluminum salts activate the NALP3 inflammasome through phagosomal destabilization. Nat Immunol (2008) 9:847. doi:10.1038/ni.1631

166. Lima H Jr, Jacobson LS, Goldberg MF, Chandran K, Diaz-Griffero F, Lisanti MP, et al. Role of lysosome rupture in controlling Nlrp3 signaling and necrotic cell death. Cell Cycle (2013) 12:1868-78. doi:10.4161/cc.24903

167. Hari A, Zhang Y, Tu Z, Detampel P, Stenner M, Ganguly A, et al. Activation of NLRP3 inflammasome by crystalline structures via cell surface contact. Sci Rep (2014) 4:7281. doi:10.1038/srep07281

168. Newman ZL, Leppla SH, Moayeri M. CA-074Me protection against anthrax lethal toxin. Infect Immun (2009) 77:4327-36. doi:10.1128/IAI.00730-09

169. Orlowski GM, Colbert JD, Sharma S, Bogyo M, Robertson SA, Rock KL. Multiple cathepsins promote pro-IL-1beta synthesis and NLRP3-mediated IL-1beta activation. J Immunol (2015) 195:1685-97. doi:10.4049/jimmunol. 1500509 
170. Orlowski GM, Sharma S, Colbert JD, Bogyo M, Robertson SA, Kataoka H, et al. Frontline science: multiple cathepsins promote inflammasomeindependent, particle-induced cell death during NLRP3-dependent IL-1beta activation. J Leukoc Biol (2017) 102:7-17. doi:10.1189/jlb.3HI0316-152R

171. Petrilli V, Papin S, Dostert C, Mayor A, Martinon F, Tschopp J. Activation of the NALP3 inflammasome is triggered by low intracellular potassium concentration. Cell Death Differ (2007) 14:1583-9. doi:10.1038/sj.cdd. 4402195

172. Lamkanfi M, Mueller JL, Vitari AC, Misaghi S, Fedorova A, Deshayes K, et al. Glyburide inhibits the cryopyrin/Nalp3 inflammasome. J Cell Biol (2009) 187:61-70. doi:10.1083/jcb.200903124

173. Bezanilla F. How membrane proteins sense voltage. Nat Rev Mol Cell Biol (2008) 9:323-32. doi:10.1038/nrm2376

174. Cala PM. Volume regulation by flounder red blood cells: the role of the membrane potential. JExp Zool (1977) 199:339-44. doi:10.1002/jez. 1401990307

175. Daut J, Standen NB, Nelson MT. The role of the membrane potential of endothelial and smooth muscle cells in the regulation of coronary blood flow. J Cardiovasc Electrophysiol (1994) 5:154-81. doi:10.1111/j.1540-8167.1994. tb01156.x

176. Sundelacruz S, Levin M, Kaplan DL. Role of membrane potential in the regulation of cell proliferation and differentiation. Stem Cell Rev (2009) 5:231-46. doi:10.1007/s12015-009-9080-2

177. Zhou Y, Wong CO, Cho KJ, van der Hoeven D, Liang H, Thakur DP, et al. SIGNAL TRANSDUCTION. Membrane potential modulates plasma membrane phospholipid dynamics and K-Ras signaling. Science (2015) 349:873-6. doi:10.1126/science.aaa5619

178. Horng T. Calcium signaling and mitochondrial destabilization in the triggering of the NLRP3 inflammasome. Trends Immunol (2014) 35:253-61. doi:10.1016/j.it.2014.02.007

179. Murakami T, Ockinger J, Yu J, Byles V, McColl A, Hofer AM, et al. Critical role for calcium mobilization in activation of the NLRP3 inflammasome. Proc Natl Acad Sci U S A (2012) 109:11282-7. doi:10.1073/pnas.1117765109

180. Lee G-S, Subramanian N, Kim AI, Aksentijevich I, Goldbach-Mansky R, Sacks DB, et al. The calcium-sensing receptor regulates the NLRP3 inflammasome through Ca2+ and cAMP. Nature (2012) 492:123-7. doi:10.1038/ nature 11588

181. Katsnelson MA, Rucker LG, Russo HM, Dubyak GR. K+ efflux agonists induce NLRP3 inflammasome activation independently of Ca2+ signaling. J Immunol (2015) 194(8):3937-52. doi:10.4049/jimmunol.1402658

182. Yaron JR, Gangaraju S, Rao MY, Kong X, Zhang L, Su F, et al. K(+) regulates $\mathrm{Ca}(2+)$ to drive inflammasome signaling: dynamic visualization of ion flux in live cells. Cell Death Dis (2015) 6:e1954. doi:10.1038/cddis.2015.277

183. Fröhlich E. The role of surface charge in cellular uptake and cytotoxicity of medical nanoparticles. Int J Nanomedicine (2012) 7:5577-91. doi:10.2147/ IJN.S36111

184. Morishige T, Yoshioka Y, Inakura H, Tanabe A, Narimatsu S, Yao X, et al. Suppression of nanosilica particle-induced inflammation by surface modification of the particles. Arch Toxicol (2012) 86:1297-307. doi:10.1007/ s00204-012-0823-5

185. Nel A, Xia T, Mädler L, Li N. Toxic potential of materials at the nanolevel. Science (2006) 311:622-7. doi:10.1126/science.1114397

186. Saquib Q, Al-Khedhairy AA, Siddiqui MA, Abou-Tarboush FM, Azam A, Musarrat J. Titanium dioxide nanoparticles induced cytotoxicity, oxidative stress and DNA damage in human amnion epithelial (WISH) cells. Toxicol In Vitro (2012) 26:351-61. doi:10.1016/j.tiv.2011.12.011

187. Zhang Z, Shen H-M, Zhang Q-F, Ong C-N. Involvement of oxidative stress in crystalline silica-induced cytotoxicity and genotoxicity in rat alveolar macrophages. Environ Res (2000) 82:245-52. doi:10.1006/enrs.1999.4025

188. Gagné F, editor. Chapter 6 - oxidative stress. Biochemical Ecotoxicology. Oxford: Academic Press (2014). p. 103-15.

189. Vallyathan V, Robinson V, Reasor M, Stettler L, Bernstein R. Comparative in vitro cytotoxicity of volcanic ashes from Mount St. Helens, El Chichon, and Galunggung. J Toxicol Environ Health (1984) 14:641-54. doi:10.1080/ 15287398409530614

190. Gao N, Keane MJ, Ong T, Wallace WE. Effects of simulated pulmonary surfactant on the cytotoxicity and DNA-damaging activity of respirable quartz and kaolin. J Toxicol Environ Health A (2000) 60:153-67. doi:10.1080/ 009841000156466
191. Lee W, Ahn Y-S, Lee S, Song BM, Hong S, Yoon J-H. Occupational exposure to crystalline silica and gastric cancer: a systematic review and meta-analysis. Occup Environ Med (2016) 73(11):794-801. doi:10.1136/oemed-2016103552

192. McLaughlin JK, Chow WH, Levy LS. Amorphous silica: a review of health effects from inhalation exposure with particular reference to cancer. $J$ Toxicol Environ Health (1997) 50:553-66. doi:10.1080/15287399709532054

193. Freire J, Ajona D, de Biurrun G, Agorreta J, Segura V, Guruceaga E, et al. Silica-induced chronic inflammation promotes lung carcinogenesis in the context of an immunosuppressive microenvironment. Neoplasia (2013) 15:913-24. doi:10.1593/neo.13310

194. O'Brien A, Scher I, Formal S. Effect of silica on the innate resistance of inbred mice to Salmonella typhimurium infection. Infect Immun (1979) 25:513-20.

195. Yarahmadi A, Zahmatkesh MM, Ghaffari M, Mohammadi S, Labbafinejad Y, Seyedmehdi SM, et al. Correlation between silica exposure and risk of tuberculosis in Lorestan province of Iran. Tanaffos (2013) 12:34-40.

196. Steenland K, Goldsmith DF. Silica exposure and autoimmune diseases. Am J Ind Med (1995) 28:603-8. doi:10.1002/ajim.4700280505

197. Sun L, Li Y, Liu X, Jin M, Zhang L, Du Z, et al. Cytotoxicity and mitochondrial damage caused by silica nanoparticles. Toxicol In Vitro (2011) 25:1619-29. doi:10.1016/j.tiv.2011.06.012

198. Joshi GN, Knecht DA. Silica phagocytosis causes apoptosis and necrosis by different temporal and molecular pathways in alveolar macrophages. Apoptosis (2013) 18:271-85. doi:10.1007/s10495-012-0798-y

199. Eguchi Y, Shimizu S, Tsujimoto Y. Intracellular ATP levels determine cell death fate by apoptosis or necrosis. Cancer Res (1997) 57:1835-40.

200. Nomura J, So A, Tamura M, Busso N. Intracellular ATP decrease mediates NLRP3 inflammasome activation upon nigericin and crystal stimulation. J Immunol (2015) 195:5718-24. doi:10.4049/jimmunol.1402512

201. Li H, Willingham SB, Ting JP-Y, Re F. Cutting edge: inflammasome activation by alum and alum's adjuvant effect are mediated by NLRP3. J Immunol (2008) 181:17-21. doi:10.4049/jimmunol.181.1.17

202. Sharp FA, Ruane D, Claass B, Creagh E, Harris J, Malyala P, et al. Uptake of particulate vaccine adjuvants by dendritic cells activates the NALP3 inflammasome. Proc Natl Acad Sci U S A (2009) 106:870-5. doi:10.1073/ pnas. 0804897106

203. Lin W, Stayton I, Huang Y-W, Zhou X-D, Ma Y. Cytotoxicity and cell membrane depolarization induced by aluminum oxide nanoparticles in human lung epithelial cells A549. Toxicol Environ Chem (2008) 90:983-96. doi:10.1080/02772240701802559

204. Popa-Nita O, Rollet-Labelle E, Thibault N, Gilbert C, Bourgoin SG, Naccache PH. Crystal-induced neutrophil activation. IX. Syk-dependent activation of class Ia phosphatidylinositol 3-kinase. J Leukoc Biol (2007) 82:763-73. doi:10.1189/ jlb.0307174

205. Cao Z, Fang Y, Lu Y, Qian F, Ma Q, He M, et al. Exposure to nickel oxide nanoparticles induces pulmonary inflammation through NLRP3 inflammasome activation in rats. Int J Nanomedicine (2016) 11:3331-46. doi:10.2147/IJN.S106912

206. Khan MI, Mohammad A, Patil G, Naqvi SA, Chauhan LK, Ahmad I. Induction of ROS, mitochondrial damage and autophagy in lung epithelial cancer cells by iron oxide nanoparticles. Biomaterials (2012) 33:1477-88 . doi:10.1016/j.biomaterials.2011.10.080

207. Jia G, Wang H, Yan L, Wang X, Pei R, Yan T, et al. Cytotoxicity of carbon nanomaterials: single-wall nanotube, multi-wall nanotube, and fullerene. Environ Sci Technol (2005) 39:1378-83. doi:10.1021/es048729l

208. Montenegro Raudales JL, Yoshimura A, Sm Z, Kaneko T, Ozaki Y, Ukai T, et al. Dental calculus stimulates interleukin- $1 \beta$ secretion by activating NLRP3 inflammasome in human and mouse phagocytes. PLoS One (2016) 11:e0162865. doi:10.1371/journal.pone.0162865

209. Reisetter AC, Stebounova LV, Baltrusaitis J, Powers L, Gupta A, Grassian VH, et al. Induction of inflammasome-dependent pyroptosis by carbon black nanoparticles. J Biol Chem (2011) 286:21844-52. doi:10.1074/jbc.M111. 238519

210. Choi AO, Cho SJ, Desbarats J, Lovrić J, Maysinger D. Quantum dot-induced cell death involves Fas upregulation and lipid peroxidation in human neuroblastoma cells. J Nanobiotechnology (2007) 5:1. doi:10.1186/14773155-5-1

211. Mulay SR, Kulkarni OP, Rupanagudi KV, Migliorini A, Darisipudi MN, Vilaysane A, et al. Calcium oxalate crystals induce renal inflammation 
by NLRP3-mediated IL-1beta secretion. J Clin Invest (2013) 123:236-46. doi:10.1172/JCI63679

212. Schorn C, Janko C, Latzko M, Chaurio R, Schett G, Herrmann M. Monosodium urate crystals induce extracellular DNA traps in neutrophils, eosinophils, and basophils but not in mononuclear cells. Front Immunol (2012) 3:277. doi:10.3389/fimmu.2012.00277

213. Desai J, Kumar SV, Mulay SR, Konrad L, Romoli S, Schauer C, et al. PMA and crystal-induced neutrophil extracellular trap formation involves RIPK1RIPK3-MLKL signaling. Eur J Immunol (2016) 46:223-9. doi:10.1002/ eji.201545605
Conflict of Interest Statement: The authors declare that the research was conducted in the absence of any commercial or financial relationships that could be construed as a potential conflict of interest.

Copyright $\odot 2018$ Shu and Shi. This is an open-access article distributed under the terms of the Creative Commons Attribution License (CC BY). The use, distribution or reproduction in other forums is permitted, provided the original author(s) and the copyright owner are credited and that the original publication in this journal is cited, in accordance with accepted academic practice. No use, distribution or reproduction is permitted which does not comply with these terms. 